\title{
The role of anthropogenic habitats in freshwater mussel conservation
}

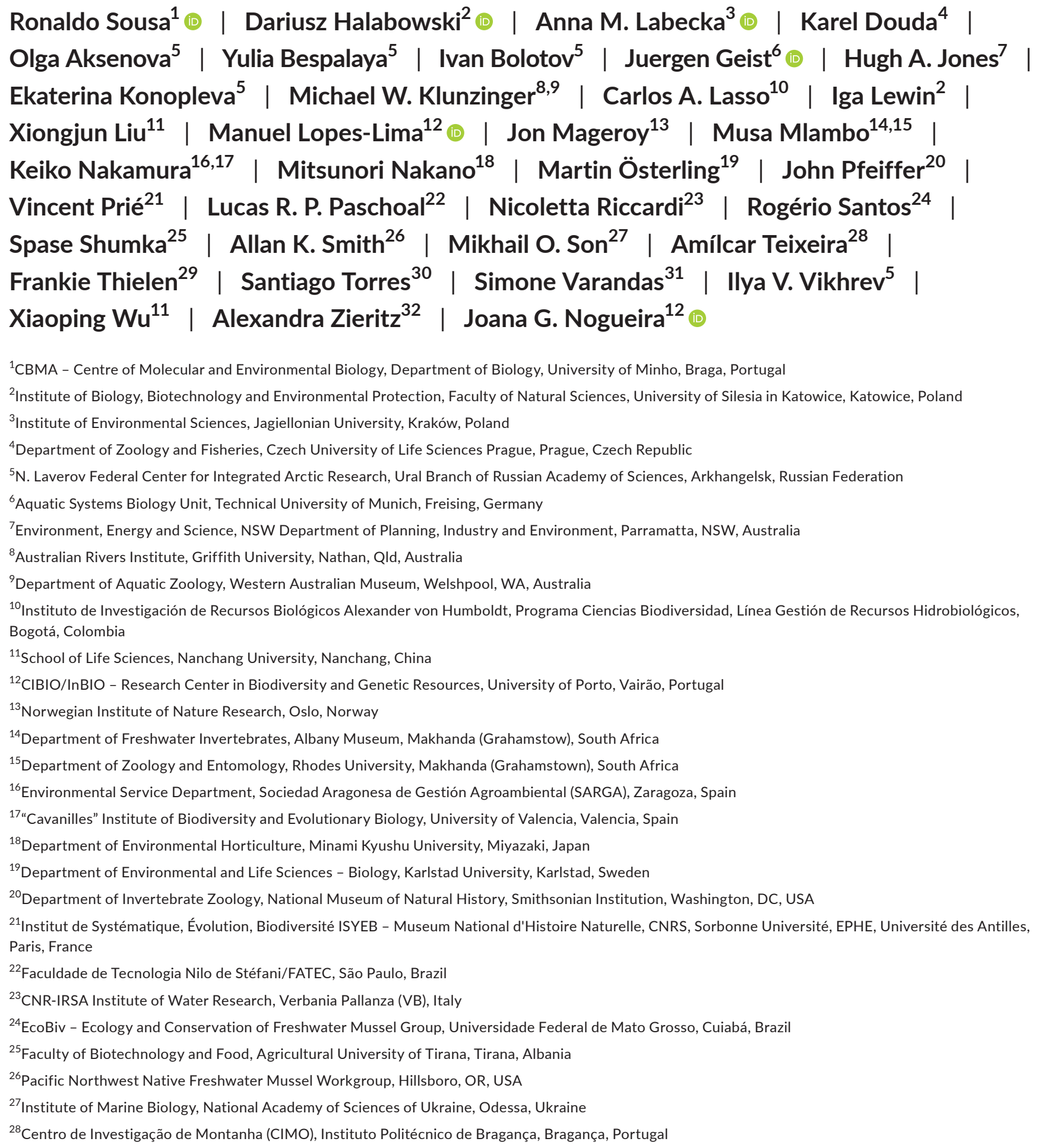


${ }^{29}$ natur and ëmwelt/Fondation Hëllef fir d'Natur, Heinerscheid, Luxembourg

${ }^{30}$ Centro de Investigaciones y Transferencia (CONICET, UNPA, UTN), Unidad Académica San Julián, Santa Cruz, Argentina

${ }^{31}$ CITAB-UTAD - Centre for Research and Technology of Agro-Environment and Biological Sciences, Forestry Department, University of Trás-os-Montes and Alto Douro, Vila Real, Portugal

${ }^{32}$ School of Geography, University of Nottingham, Nottingham, UK

\section{Correspondence}

Ronaldo Sousa, CBMA - Centre of

Molecular and Environmental Biology,

Department of Biology, University of

Minho, Campus Gualtar, 4710-057 Braga,

Portugal.

Email:rg.eco.sousa@gmail.com

\section{Funding information}

COST project, Grant/Award Number: CA18239; Institute of Environmental Sciences Jagiellonian University, Grant/ Award Number: N18/DBS/000003;

Aragón Government

\begin{abstract}
Anthropogenic freshwater habitats may provide undervalued prospects for long-term conservation as part of species conservation planning. This fundamental, but overlooked, issue requires attention considering the pace that humans have been altering natural freshwater ecosystems and the accelerated levels of biodiversity decline in recent decades. We compiled 709 records of freshwater mussels (Bivalvia, Unionida) inhabiting a broad variety of anthropogenic habitat types (from small ponds to large reservoirs and canals) and reviewed their importance as refuges for this faunal group. Most records came from Europe and North America, with a clear dominance of canals and reservoirs. The dataset covered 228 species, including 34 threatened species on the IUCN Red List. We discuss the conservation importance and provide guidance on how these anthropogenic habitats could be managed to provide optimal conservation value to freshwater mussels. This review also shows that some of these habitats may function as ecological traps owing to conflicting management practices or because they act as a sink for some populations. Therefore, anthropogenic habitats should not be seen as a panacea to resolve conservation problems. More information is necessary to better understand the trade-offs between human use and the conservation of freshwater mussels (and other biota) within anthropogenic habitats, given the low number of quantitative studies and the strong biogeographic knowledge bias that persists.
\end{abstract}

\section{KEYWORDS}

ecological traps, freshwater biodiversity, novel ecosystems, sink habitats, unionids

\section{1 | INTRODUCTION}

Humans have long been recognised as the dominant species on the planet, with the ability to change terrestrial and aquatic ecosystems physically, chemically and biologically, using tools and technology that are beyond the capacity of other species (Ellis \& Ramankutty, 2008). Human interactions with natural ecosystems range from the relatively small impacts of primeval hunter-gatherers (but see possible effects of overexploitation; Barnosky, 2008) to complete replacement by built infrastructure (Smith, 2007). For example, since ancient times, humans have tried to control freshwater ecosystems by constructing irrigation canals, dams, dykes and ponds, with varying ecological impacts. The first large anthropogenic structures (i.e. human-created or heavily modified ecosystems sensu Lundholm \& Richardson, 2010) in aquatic ecosystems appeared in Mesopotamia and Egypt and were mainly constructed for irrigation purposes (Geyer \& Monchambert, 2015; Ortloff, 2009; Smith, 1971). Subsequent civilisations also substantially modified freshwater ecosystems and remarkable historical examples, now classified as UNESCO World Heritage Sites, include the Aflaj Irrigation Systems in Oman, the Chaco irrigation system in the San Juan Basin (USA), the highly complex hydraulic structures in Angkor (Cambodia) and Champaner-Pavagadh (India), and the Subak system in Bali (Indonesia).

Recently, the number of anthropogenic structures in aquatic ecosystems has skyrocketed and few large rivers remain that are devoid of large barriers blocking their connectivity (Barbarossa et al., 2020; Grill et al., 2019). Such infrastructures have high social, political, historical and economic value, since they are seen as fundamental production tools for irrigated agriculture, energy production, transportation of goods, and are also important for human leisure activities (Aspe \& Jacqué, 2015; Lin et al., 2020).

Anthropogenic habitats are colonised by distinct biological communities when compared to natural ecosystem counterparts, owing to differences in resource availability, stress intensity, disturbance and 
environmental characteristics (Chester \& Robson, 2013; Lundholm \& Richardson, 2010). Due to these differences, anthropogenic habitats often have negative impacts on biodiversity, but may also serve as refuges for some species. In fact, in recent years, reconciliation ecology (sensu Rosenzweig, 2003) argues that we need to embrace these anthropogenic habitats to conserve biodiversity, given the pace of destruction of natural habitats and because they may provide a safe haven for some species with threatened conservation status. Interesting examples can be found in the literature and several aquatic species, some with threatened status, are shown to benefit from the presence of artificial infrastructures. These include the importance of artificial ponds for amphibians and man-made reservoirs listed as Ramsar sites due to their significance for wetland birds (Chester \& Robson, 2013). Artificial habitats may function as important corridors for dispersal and migration, and provide secure refuges during extreme climatic events (e.g. droughts, heatwaves). On the other hand, these anthropogenic habitats can have negative effects on biodiversity as well, such as the introduction of invasive species, and lower genetic diversity of native populations, and therefore become ecological traps (i.e. habitats preferred by animals despite resulting in lower fitness compared to other available options; Schlaepfer et al., 2002) or sink habitats (i.e. habitats that are net importers of individuals, because local reproduction is not sufficient to balance local mortality; Pulliam, 1988).

Freshwater mussels of the order Unionida comprise a highly diverse group of organisms (more than 800 species) present in all continents except Antarctica (Lopes-Lima et al., 2014, 2018). These organisms colonise a great diversity of aquatic habitats, ranging from small streams and ponds to large rivers and lakes, and in recent years they have gained scientific and media attention due to the rapid decline in abundance and distribution (Lopes-Lima et al., 2017; Strayer et al., 2004; Zieritz, Bogan, Froufe, et al., 2018). A myriad of threats have been mentioned as responsible for these declines, and usually encompass habitat loss and fragmentation, pollution, overexploitation, climate change and introduction of invasive alien species (Ferreira-Rodríguez et al., 2019). In addition, these organisms have an unusual life cycle, which depends on fish hosts, with some species living for more than 100 years (for a review, see Modesto et al., 2018). Given these threats and the peculiar reproductive strategy, about $45 \%$ of all species assessed by the IUCN are currently near-threatened, threatened or extinct (LopesLima et al., 2018).

Recently, some studies suggested the potential importance of anthropogenic habitats in conserving threatened freshwater mussels (e.g. Araujo \& Ramos, 2000; Sousa, Nogueira, Lopes-Lima, et al., 2019; Sousa, Teixeira, et al., 2019), while others emphasised their role in promoting the spread of invasive species, even in remote areas (Zieritz, Bogan, Rahim, et al., 2018). In this review, we analyse available data on freshwater mussels inhabiting anthropogenic habitats to assess their importance as stable refuges or ecological traps. Based on our findings, we subsequently discuss opportunities and challenges to promote overall freshwater mussel conservation in these anthropogenic habitats.

\section{ANTHROPOGENIC HABITATS FOR FRESHWATER MUSSELS}

Data on freshwater mussel populations inhabiting anthropogenic environments were initially collected through a bibliographic search using ISI Web of Science and Google Scholar using the terms ('anthropogenic' or 'artificial' or 'canal' or 'dam' or 'novel' or 'port' or 'reservoir' or 'rice paddy') and ('freshwater mussel' or 'freshwater bivalve' or 'unionid'). As this bibliographic search retrieved a low number of records, personal data and grey literature collected and verified by the authors of this study were added to the database. In addition, we searched the IUCN Red List (IUCN, 2020) for freshwater mussels with information on artificial habitats. If the information in the IUCN Red List had not been captured in earlier bibliographic searches, we added these records to the overall database. Each record was assigned to one anthropogenic habitat category following Chester and Robson (2013). Category 'canal' thereby included structures used for different purposes, including navigation, irrigation, ditches, and canals present in rice paddies and farmland. Similarly, category 'reservoir' included lentic habitats resulting from dams, weirs or related constructions, and category 'artificial ponds' included structures constructed for fish production, recreation or other human activities. We recognise that these categories are an oversimplification in terms of human use, but the respective habitats grouped within these categories are similar in terms of their environmental characteristics, and thus, they are adequate in framing their respective importance to freshwater mussels. It should be noted that examples comprising small weirs or similar obstacles (less than $1 \mathrm{~m}$ high), bridges and culverts were not considered here due to the strong spatial restriction of their potential impacts on freshwater mussels. Also, river sections immediately downstream of dams or river sections subjected to thermal pollution, caused by warm water released from power plants, were not considered. For each record, we collected information on the geographic location and the species of freshwater mussel present; described the environmental characteristics of the habitat and made a comparison to adjacent natural habitats if possible; extracted quantitative data on the autecology of the species present (e.g. density, biomass and size estimates); and determined whether the anthropogenic habitat functions as an ecological trap (as described above) and if non-native bivalve species are present.

In total, we compiled 709 records of anthropogenic habitats inhabited by freshwater mussels (see Figure 1 for a summary of examples distributed worldwide and Table S1 for the complete listing). For the great majority of records (83.5\%), data are restricted to the identities of the species present (Table S1), while $16.5 \%$ of records contain quantitative data concerning at least one basic autecological characteristic (usually density and/or size estimates; Table S1).

Our data indicate that freshwater mussels can colonise canals (including irrigation, transport, and cooling canals, water mills and ditches), channelised rivers, reservoirs (including mining subsidence reservoirs), artificial ponds, artificial lakes (including urban and sandpit lakes), rice paddies, navigational pools and ports (Figure 2a). The dataset is dominated by records from canals and reservoirs, a result that was expected given the number and extension of canals 


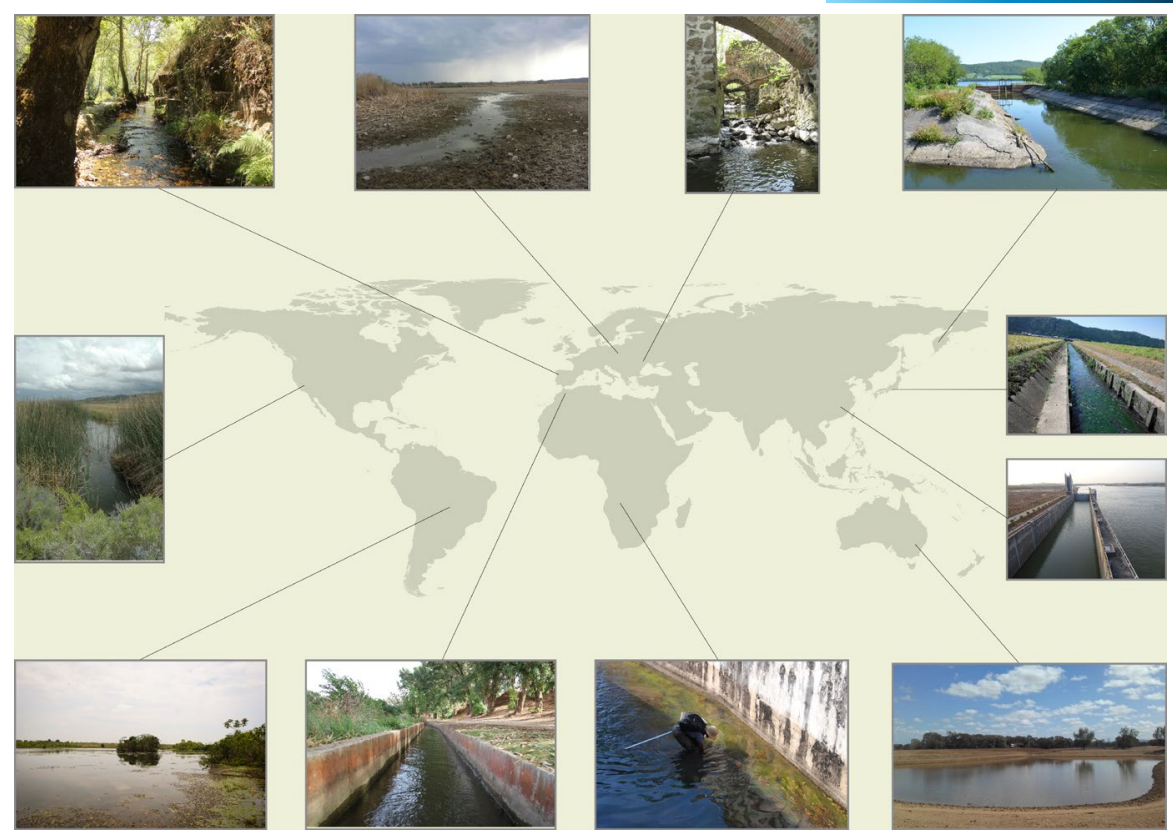

FIGURE 1 Examples of anthropogenic habitats colonised by freshwater mussels. From the upper left corner and in clockwise direction examples include: Water Mill Canal in the Tuela River (Portugal) colonised by Margaritifera margaritifera; Smolicki fishpond (Poland) colonised by the non-native Sinanodonta woodiana; Water Mill Canal in Bug River (Ukraine) colonised by Unio crassus, Unio pictorum and Unio tumidus; Canal of the Petropavlovsk-Kamchatsky Thermal Power Plant (Russia) colonised by Beringiana beringiana; Canal Nagahama Shiga (Japan) colonised by Pronodularia japanensis, Pseudodon omiensis, Sinanodonta japonica, Lanceolaria grayana, Inversidens brandtii, Nodularia douglasiae biwae and Inversiunio yanagawensis; Canal Shihutang (China) colonised by Anemina arcaeformis, Lamprotula caveata, Nodularia douglasiae and S. woodiana; Farm dam in Isaac River (Australia) colonised by Velesunio wilsonii and Alathyria pertexta; Intake Canal in a hydropower plant in the Cubango River (Angola) colonised by Coelatura kunenensis and Mutela zambesiensis; Irrigation Canal in the Bouhlou River (Morocco) colonised by Potomida littoralis, Pseudunio marocanus and Unio foucauldianus; Urban reservoir in Cuiába (Brazil) colonised by Anodontites trapesialis and Anodontites elongatus; Double Springs Canal in Malheur National Wildlife Refuge (USA) colonised by Anodonta californiensis [Colour figure can be viewed at wileyonlinelibrary.com]

FIGURE 2 Percentage of records per type of identified anthropogenic habitat (a) and continent (b) retrieved in this review $(N=709)$ and number of species identified in those records $(N=228)$ per IUCN Red List categories (c): CR, Critically Endangered; DD, Data Deficient; EN, Endangered; LC, Least Concern; NE, Not Evaluated; NT, Near Threatened; VU, Vulnerable [Colour figure can be viewed at wileyonlinelibrary.com]
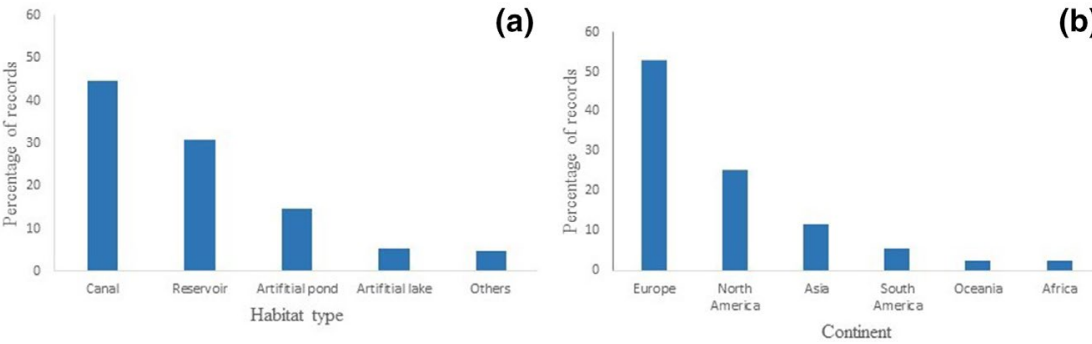

(c)

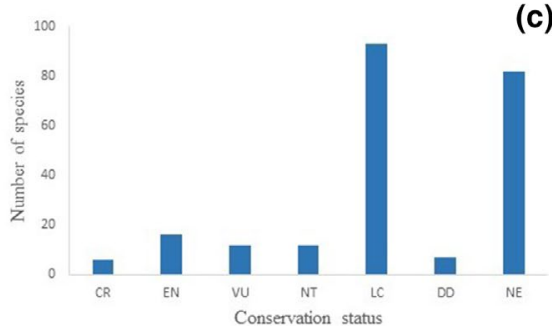

worldwide (more than 63,000 km in 1985; Revenga et al., 2000) and the high number of impoundments (2.8 million larger than 0.1 ha; Lehner et al., 2011). Somewhat unexpected was the relatively low number of records in channelised rivers, given the great extension of these structures worldwide (Schmutz \& Sendzimir, 2018). However, since freshwater mussels usually colonise areas near the banks, channelisation of rivers can be highly detrimental to these species (Haag, 2012) and this may explain the low number of records in these anthropogenic habitats. In addition, data on freshwater mussels in channelised rivers with characteristically steep margins may be artificially low due to difficulties in conducting surveys using traditional sampling techniques.

Our dataset covers all continents inhabited by freshwater mussels, with a majority from Europe and North America and very few from Africa, Oceania and South America (Figure 2b). This situation probably reflects the much greater research effort on freshwater 
mussels in Europe and North America rather than a lack of anthropogenic freshwater habitats in the other continents. This biogeographic bias follows similar trends in other areas of freshwater mussel research (Lopes-Lima et al., 2014).

Our dataset comprised a total of 228 species (Table S2), of which 34 are considered as globally threatened (i.e. Critically Endangered [6 species], Endangered [16 species] or Vulnerable [12 species]; IUCN, 2020; Figure 2c). A total of $24.1 \%$ of records include at least one non-native bivalve species, with great dominance of Sinanodonta woodiana, followed in much lower numbers by Corbicula fluminea and Dreissena polymorpha, and isolated examples concerning Limnoperna fortunei and Dreissena bugensis (Table S1).

Although to our knowledge few studies have investigated how freshwater mussels colonise anthropogenic habitats, the most probable pathway may be the dispersal of mussel larvae (glochidia) through their fish hosts. In several countries, the stocking of fish served as an efficient mechanism for the dispersal and subsequent establishment of invasive mussels such as $S$. woodiana. This species spread out across Europe, for example, by stocking of Asian carp used to control macrophytes (Huber \& Geist, 2019). Anthropogenic habitats can also function as dispersal corridors to natural habitats, exemplified by the dispersal of several unionid species (e.g. Fusconaia flava and Pyganodon grandis) from Lake Erie to Mohawk River via the Erie Canal (New York, USA; Strayer, 2008). In canals that receive water from natural ecosystems, dispersal and colonisation may be common and again, host fish may be the most probable vector of dispersal. In other cases, freshwater mussels were deliberately introduced by humans such as the case of translocation of Megalonaias nervosa specimens from the Cumberland River to the Kentucky Lake Reservoir (Kentucky and Tennessee, USA; see Table S1). On the other hand, freshwater mussels present in reservoirs mostly correspond to species that already inhabited the river before damming (Haag, 2012). After damming, the population size of those species that are better adapted to the now prevailing lentic conditions often increases considerably (see below for further discussion).

\section{3 | ANTHROPOGENIC HABITATS AS STABLE REFUGES OR ECOLOGICAL TRAPS}

\section{1 | Stable refuges}

If water, substrate, and food quality and quantity are adequate and connectivity to natural ecosystems is provided, anthropogenic ecosystems can, in some cases, be extremely important for the conservation of freshwater mussels. For example, highly threatened species such as Margaritifera margaritifera (Endangered), Pseudunio auricularius (Critically Endangered) and Pseudunio marocanus (Critically Endangered) have been found in irrigation or watermill canals that maintain suitable and stable environmental conditions. In some cases, organisms seem to be in better physiological condition and present higher density in these habitats than compared to natural conditions (Araujo \& Ramos, 2000; Sousa, Nogueira, Lopes-Lima, et al., 2019; Sousa, Teixeira, et al., 2019; see also Box 1). The confirmed presence of juveniles in these canals further indicates suitable habitat conditions for fish hosts and favourable conditions for larval survival, facilitating recruitment and juvenile growth (Sousa, Nogueira, Lopes-Lima, et al., 2019; Sousa, Teixeira, et al., 2019).

Reservoirs may support abundant and diverse mussel assemblages if the water quality remains good and in the absence of other impacts, albeit predominantly for species preferring lentic conditions (see below discussion on negative effects on lotic species). For example, in Lower Lake (Mississippi, USA), conditions favoured a highly diverse, healthy and recruiting assemblage of freshwater mussels although mostly comprised of common and widespread species, and lacking threatened species (Haag \& Warren, 2007). Similarly, certain navigation pools in large European and North American rivers are inhabited by diverse mussel assemblages (see Table $\mathrm{S1}$ ). In many regions of Australia, farm dams are readily colonised by mussel larvae of Alathyria pertexta, Velesunio ambiguus, Velesunio wilsonii and Westralunio carteri (Vulnerable), via their host fish. These farm dams serve as refuges for freshwater mussels, having otherwise been lost due to river salinisation, whilst in other cases, they provide a functional habitat similar to billabongs and waterholes (Jones, 2011; Klunzinger et al., 2015). Small instream reservoirs can also benefit A. pertexta, $\mathrm{V}$. ambiguus and, to a lesser degree, Hyridella australis, which thrive in the characteristic lacustrine and muddy conditions (Brainwood et al., 2008; Byrne, 1998; Jones, 2007; Walker, 1981, 2017; Walker et al., 1992).

In some of the typically temporary or ephemeral rivers and streams of arid or semi-arid regions, earthen block banks are built across the channel to supply water. In the lower Darling River (Australia), these artificial structures provide a refuge for Alathyria jacksoni during droughts due to higher availability of water. In the Isaac River, Queensland (Australia), the type locality of Velesunio wilsonii is a 'waterhole' with modified embankments, which is used to supply cattle with water (McMichael \& Hiscock, 1958). In the south of Morocco, irrigation canals serve as a refuge for Potomida littoralis (Endangered) as they present more stable hydrological conditions and lower temperature than natural ecosystems, which experience increasingly lengthy and severe periods of drought due to climate change and/or water abstraction for agriculture and domestic use (Gomes-dos-Santos et al., 2019).

If managed carefully and the water levels in the canals are maintained, rice paddy fields can also be a refuge for some species, as described in several examples in Japan and Spain (Table S1). This type of habitat covers extensive areas in Asia, and their conservation may be crucial at regional scales, given the disturbance of natural ecosystems. Unfortunately, we were unable to retrieve many records from Asia, but this situation warrants further investigation.

Fish ponds are one of the oldest types of anthropogenic freshwater habitats. First occurring in China by around 6000 BC (Nakajima et al., 2019), these habitats began to spread rapidly in the inland areas of Europe during the Late Middle Ages (especially the 14th and 15th centuries; Hoffmann, 1996). In this review, a large number of fish ponds were identified as suitable refuges for several freshwater mussel species. The medieval pond system of the Třeboňsko Biosphere Reserve, Czech Republic is a particularly interesting example (see Box 2). 


\section{BOX 1 Irrigation canals as critical habitat for two of the rarest freshwater species}

In the western Mediterranean, two range-restricted long-lived freshwater mussels have been part of ongoing conservation actions over the last decade. Pseudunio auricularius is now restricted to a few river basins in Spain and France whereas $P$. marocanus is restricted to the Sebou and Oum Er Rbia basins in Morocco (Nakamura, Cucala, et al., 2018; Nakamura et al., 2018; Prié et al., 2018; Sousa, Teixeira, et al., 2018; Sousa et al., 2016). Both species have been found in anthropogenic habitats (irrigation canals), which seem to provide stable conditions for their growth, reproduction and survival.

In Spain, P. auricularius appears to have colonised the Canal Imperial de Aragón (Figure B1a) during historical times, although it was not discovered there until 1996 (Araujo \& Ramos, 1998, 2000). Built in the 18th century, the Canal Imperial was an important engineering scheme in Europe, constructed for both irrigation and navigation purposes, and is $108 \mathrm{~km}$ long with a $30 \mathrm{~m}^{3} / \mathrm{s}$ mean water discharge. Nowadays, it still supplies water for agriculture and industrial activities, and for the main city of the region (Zaragoza). The first $32 \mathrm{~km}$ of the canal are made of concrete, whereas the remaining $76 \mathrm{~km}$ are composed of a natural substrate with gravel and silt, retaining a stable water level throughout the year, which makes it an ideal habitat for freshwater mussels. However, annual maintenance works (Figure B1c) are responsible for the replacement of natural earth slopes by stone or concrete walls or even transverse lock gates, which can harm P. auricularius and other species such as Anodonta anatina, Potomida littoralis and Unio mancus. Nowadays, the latter three species appear to have disappeared from the canal, although they were highly abundant 20 years ago (Araujo \& Ramos, 1998, 2000). The only freshwater bivalves that are still present in the Canal are the flagship species $P$. auricularius and two non-native species, Dreissena polymorpha and Corbicula fluminea. Since 2013 , more than 4000 individuals of $P$. auricularius have been found dead in Canal Imperial and the causes are under investigation (Nakamura et al., 2020).

In Morocco, a great number of $P$. marocanus individuals can be found in the irrigation infrastructure present in the downstream part of the Bouhlou River (Sebou basin) (Figure B1b). This infrastructure comprises two main irrigation canals branching into smaller ditches managed by local farmers. The construction of the right canal ( $7 \mathrm{~km}$ of extension) in 1967 and the left canal ( $3 \mathrm{~km}$ of extension) in $1992 \mathrm{were}$ part of a national project that aimed to enlarge the irrigation area. Both canals have a width of approximately $1 \mathrm{~m}$, a maximum depth of $80 \mathrm{~cm}$ and are connected to the Bouhlou River by the presence of two small weirs, which divert the water from the river to the canals. In 2016 , during a survey, Sousa, Teixeira, et al. (2019) found P. marocanus in the left canal. Further surveys showed that the individuals colonising the irrigation canal located on the left bank have a significantly higher density and condition index when compared to adjacent natural habitats, but no differences were found regarding individuals' size (Sousa, Teixeira, et al., 2019). These canals are also colonised by P. littoralis, Unio foucauldianus and by the non-native $C$. fluminea. Despite the conservation importance, local authorities reported dredging and cleaning activities by local farmers leading to high mortalities (Figure B1d); reduction of these impacts is now the focus of several outreach activities.
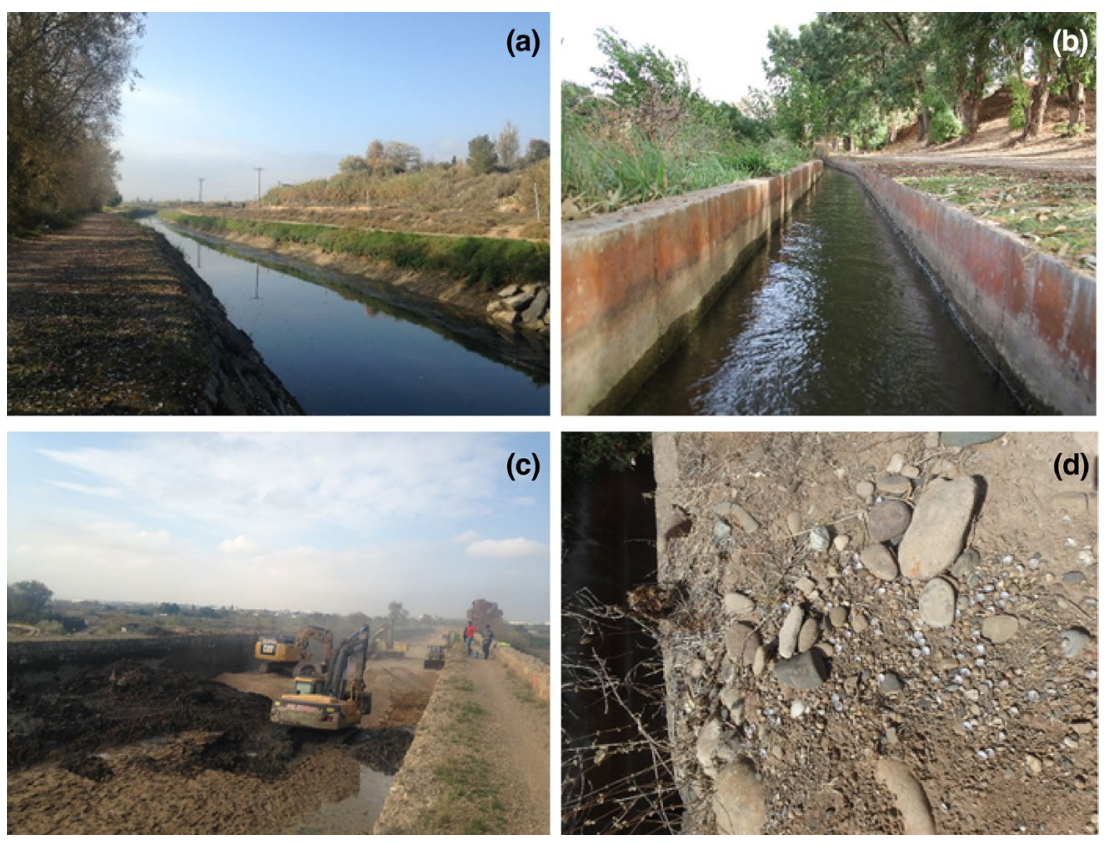

BOX FIGURE B1 Canal Imperial in Aragon (Spain) (a), Bouhlou Irrigation Canal (Morocco) (b), maintenance works in the Canal Imperial (c) and sediment and empty shells of several bivalve species after cleaning activities by farmers in the Bouhlou Irrigation Canal (d) [Colour figure can be viewed at wileyonlinelibrary.com] 


\section{BOX 2 Medieval pond system of the Třeboňsko Biosphere Reserve (Czech Republic)}

The medieval fishpond system in the Třeboňsko Biosphere Reserve (TBR) was built in the 14th to 16th century to farm common carp (Cyprinus carpio). The system contains approximately 460 artificial fishponds within an area of $70 \mathrm{~km}^{2}$ (Figure B2). This area is a Natura 2000 site (EU Birds and Habitats Directive) and was also designated as a UNESCO Biosphere Reserve in 1977. In addition, parts of the TBR were designated as a RAMSAR site (Wetlands of International Importance) in 1990. The TBR fish ponds are shallow reservoirs ( $\sim 1 \mathrm{~m}$ average water depth) enclosed by earth dams that can be completely drained to harvest fish stocks.

The TBR is inhabited by a diverse freshwater mussel fauna (five out of six Central European species of the family Unionidae) including: Anodonta cygnea, Anodonta anatina, Unio tumidus, Unio pictorum and Pseudanodonta complanata (Beran, 2019; Hronek, 2010). These artificial ponds provide crucial habitat for A. cygnea, which is the most common species in TBR, whilst elsewhere in the Czech Republic it is quite rare and protected by Czech law. The artificial pond habitats are similar to natural shallow lakes or oxbows where A. cygnea would normally be found; habitats that are mostly absent in this area or that have been destroyed by human activities. The soft, mostly muddy or muddy-sandy bottom creates suitable conditions for the movement of lentic mussels in the sediment and offers the possibility of their complete burial during the period of draining for fish harvest. The long residence time of water within these ponds allows the development of phytoplankton, which is a key source of food for mussels.

Despite the potentially high importance for lentic mussel populations, their ecology in these ponds remains relatively poorly studied compared to adjacent river habitats. Accordingly, there are almost no data on the factors that affect the usability of TBR and other pond systems for freshwater mussels. Reported mean population densities of mussels in TBR are currently low $\left(\sim 0.8\right.$ ind./100 $\mathrm{m}^{2}$; Hronek, 2010; K. Douda, personal observation, August, 2018) and the available observations indicate that the use of the ponds by mussels has several important requirements. First, the stocking density of fish populations and the level of supplementary feed can have a detrimental impact in terms of direct predation of mussels and water quality. Although the fisheries management in TBR is semiintensive and strictly regulated (fish stocking density $200-400 \mathrm{~kg} / \mathrm{ha}$; Roy et al. 2020), the current intensity seems to lead to habitats becoming unsuitable for these freshwater mussels and hence a large proportion of ponds ( 60\%) have already lost their populations. The TBR represents a unique example of ancient anthropogenic habitat, whose suitability for mussels is critically dependent on the strict regulation of economic use balanced with active species protection oriented towards the support of ecosystem functions. This strategy was developed based on the emphasis on the traditional use of ponds and conservation management of mussels and other endangered species. Populations of globally declining waterfowl, aquatic plants, amphibians and other invertebrate groups benefit from the adopted regulations. Considering the increasing pressure on adjacent natural habitats, in terms of changes in the hydrological regime, water pollution and invasive species, the importance of TBR for mussels may even increase in the future.

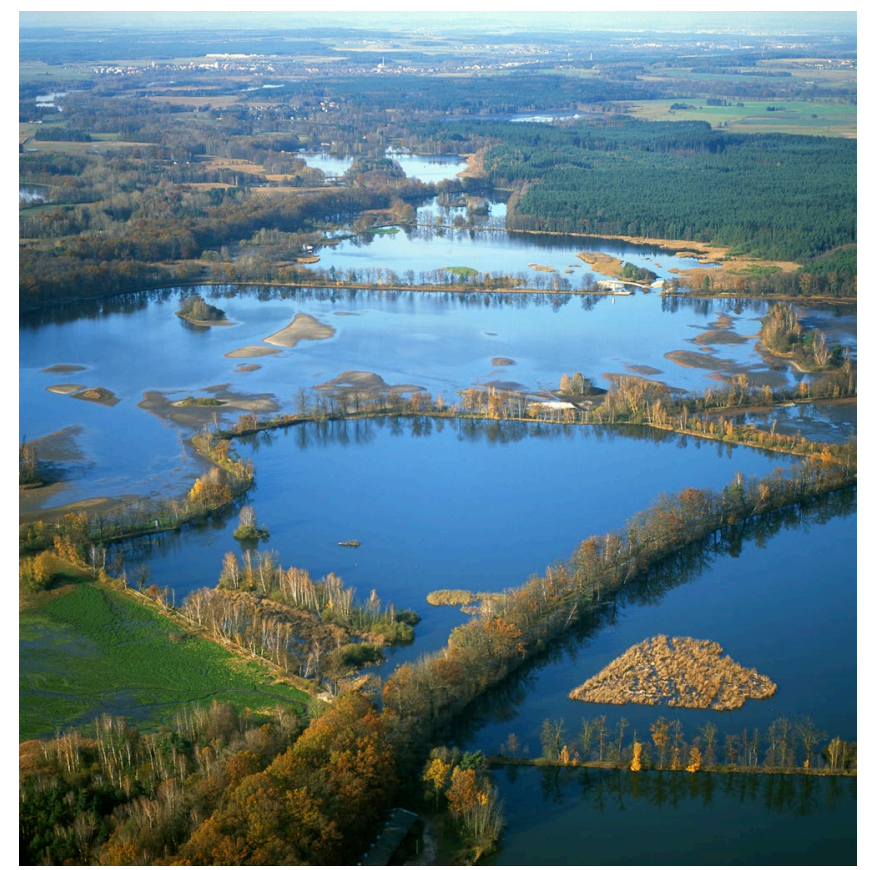

BOX FIGURE B2 Aerial view of the medieval pond system of the Třeboňsko Biosphere Reserve (photo credit: Jan Ševčík) [Colour figure can be viewed at wileyonlinelibrary.com] 


\subsection{Ecological traps}

The negative impact of anthropogenic habitats on freshwater mussels may either be linked to their characteristics, that is by providing inferior habitat conditions compared to the previous, natural environments, or as a result of their destruction or bad management. In Europe, the canals that provided water mills with power have been in decline or even lost after the mills stopped production and this has compromised the survival of many small sub-populations of pearl mussels M. margaritifera in these habitats in France and elsewhere (Sousa, Nogueira, Lopes-Lima, et al., 2019; V. Prié, personal observation, September, 2020). Other canals have disappeared due to landfills (Ghosh et al., 2020). Another threat, as shown by some examples from Japan and Morocco, is the conversion from traditional to modern irrigation techniques, which can lead to the abandonment and disappearance of some canals (Katayama et al., 2015; Natuhara, 2013; Sousa, Teixeira, et al., 2019) and negatively affect freshwater mussels and other organisms.

In other cases, the novel anthropogenic habitat provides suboptimal or completely unsuitable conditions for the naturally occurring species. Reservoirs have been shown to negatively affect freshwater mussel species (McAllister et al., 2001). The Muscle Shoals in the Tennessee River, USA, was impounded in 1924, and surveys showed that species richness declined from 71 to 43 species in the first 15 years, and thereafter, the species richness continued to decline more gradually (Haag, 2012). After the 1960s, several lentic species (Anodonta suborbiculata, Lasmigona complanata, P. grandis, Utterbackia imbecillis), that had never been recorded before impoundment, became established as viable populations (Haag, 2012). In Portugal, the construction of small dams in mountainous and oligotrophic rivers was responsible for the near disappearance of the pearl mussel M. margaritifera from areas within the reservoirs, whilst sites located downstream only retained adults without signs of recent recruitment (Sousa, Ferreira, et al., 2020). In Northern Italy, the exponential increase of small hydroelectric plants in the last decade and changes in agricultural practices (e.g. Falcucci et al., 2007) are the most probable causes of the extinction of more than $80 \%$ of the populations of Microcondylaea bonellii (Vulnerable; Albrecht et al., 2011). In Australia, although small instream reservoirs may benefit some species (see above), the lacustrine and muddy conditions created by weirs or dams are not suitable for species that prefer lotic environments, such as A. jacksoni, Hyridella depressa or Cucumerunio novaehollandiae (Brainwood et al., 2008; Jones, 2007; Walker et al., 1992). Consequently, the proliferation of small reservoirs throughout south-eastern Australian rivers, especially in the MurrayDarling Basin (Kingsford, 2000), may create mixed conservation outcomes. The most significant environmental alterations, which explained the observed patterns in reservoirs, were related to changes in sediment characteristics (accumulation of fine sediments and organic matter), temperature, suspended solids and dissolved oxygen (Haag, 2012; Sousa, Ferreira, et al., 2020).

Increased oscillation of the water level in reservoirs due to extreme climatic conditions (e.g. droughts, floods, heatwaves) or bad management of the river flow can pose a further threat to mussel populations. In Australia, the water levels of water storage reservoirs often fluctuate widely as they are drawn down seasonally for irrigation supply or because inflows to the reservoirs may decline during prolonged droughts-a situation that is projected to become increasingly more common due to climate change. This can lead to the death of large numbers of V. ambiguus and A. pertexta. In extreme cases, such as during the 2012 drought in Brazil when the water level decreased by up to $17 \mathrm{~m}$ in the Furnas HPS reservoir, water levels were still not re-established several years after the drought (Paschoal et al., 2020). This extreme situation acted as an ecological trap for the freshwater mussel Anodontites trapesialis, resulting in massive mortalities. Surveys conducted 3 years later showed a terrestrial succession with increases in organic matter and calcium in the soil caused by the decomposition of mussels (Paschoal et al., 2020; Figure 3). Very similar results were reported in reservoirs during extreme droughts in Portugal and Australia resulting in high mortalities of M. margaritifera (Sousa, Ferreira, et al., 2018) and A. pertexta and V. ambiguus (M. W. Klunzinger, personal observation, January, 2010 and 2017), respectively. In the same vein,
FIGURE 3 Variation of the water level at Furnas HPS reservoir (Sapucaí River, Minas Gerais, Brazil), from 2011 to 2016, in response to extreme drought and consequent transition from an aquatic to a terrestrial ecosystem. In November 2012, the drought was responsible for massive mortalities of the freshwater mussel Anodontites trapesialis, resulting in an ecological trap for this population [Colour figure can be viewed at wileyonlinelibrary. com]

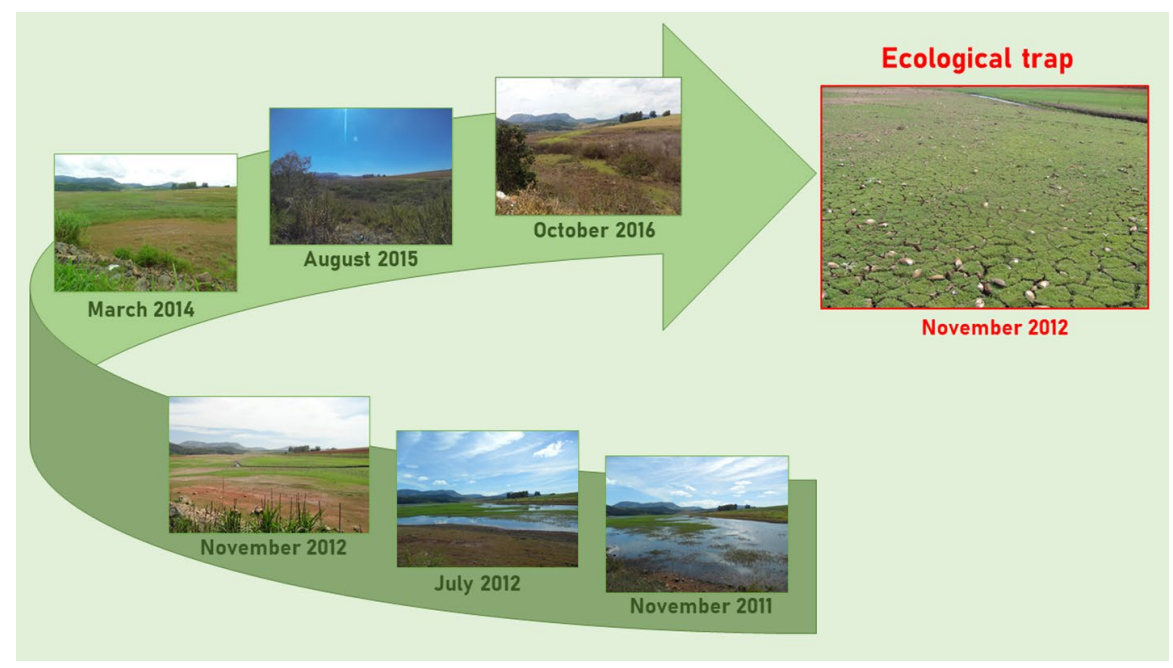


maintenance works in reservoirs may result in ecological traps. For example, in south-western Australia, W. carteri may colonise water supply dams (Beatty \& Morgan, 2017; Klunzinger et al., 2015), but mortalities have occurred when mussels became stranded in drying mud, being exposed to heat and direct sunlight during rapid water releases associated with dam maintenance works (Lymbery et al. 2020).

Ecological traps in anthropogenic habitats can also be a result of cleaning or maintenance activities in large sections of canals, which may cause massive mortalities of freshwater mussels. In Morocco, Sousa, Teixeira, et al. (2019) reported that frequent dredging and cleaning activities by local farmers on the Bouhlou irrigation canals were performed without any special attention devoted to biodiversity, causing massive mortalities of $P$. marocanus (Critically Endangered), U. foucauldianus (Critically Endangered) and $P$. littoralis (Endangered). In the Canal Imperial (Spain) and numerous other irrigation canals (e.g. Miura et al., 2018 in Japan), natural banks are frequently replaced by those made of concrete or large stones. Such bank replacement can be deleterious for $P$. auricularius (Critically Endangered) and many other species directly, by altering habitat conditions, and indirectly, by negatively affecting their host fish populations. In Australia, artificial drainage canals tend to support lower mussel densities than natural habitats, as they are often devoid of shading riparian vegetation and complex instream habitat (e.g. woody debris), and have large numbers of introduced cyprinids (e.g. Carassius auratus), which are unsuitable hosts (Klunzinger et al., 2012). Drying of ponds due to droughts or due to cleaning activities can also result in high mortalities of freshwater mussels. In Poland, a great number of fish ponds that are colonised by freshwater mussels may dry in the summer due to droughts or drain age by the owners for commercial (fish trade) or cleaning purposes. In some cases, fish ponds remained dry from autumn to spring, with mortality of freshwater mussels within the ponds and also in receiving streams, due to high fine sediment input (Hoess \& Geist, 2020). Similarly, in 2003 on the Malheur National Wildlife Refuge, Oregon (USA), the Benson Pond was drained to kill common carp and aquatic vegetation, which resulted in the mortality of Anodonta nuttalliana (Vulnerable) and Anodonta oregonensis (A. Smith, personal observation, 2003). In some cases, the drying of these fish ponds may trap a dense population of the invasive $S$. woodiana. In Myanmar, S. woodiana individuals completely burrowed in the sediment were still alive 4 weeks after drying, but if this situation had persisted this would result in massive mortalities of this invasive species (I. Bolotov and I. V. Vikhrev, personal observation, March, 2020).

Some anthropogenic habitats may become ecological traps for freshwater mussels due to elevated pollution levels when compared to natural ecosystems. One example identified in this review concerns mining subsidence reservoirs in Poland, into which salinised underground mine water is being discharged. This negatively affects the survival and larval attachment of Anodonta anatina and Anodonta cygnea (Beggel \& Geist, 2015). Organic pollution is known to impair the survival of many native freshwater mussel species whilst favouring invasive species, such as S. woodiana, across natural and anthropogenic habitats worldwide (Zieritz, Bogan, Rahim, et al., 2018; Zieritz et al., 2016). However, this trend is often exacerbated in anthropogenic habitats, which are characterised by low water volume and lentic conditions. Some anthropogenic habitats can furthermore function as a trap to toxicants (e.g. dams as a trap for heavy metals; Palanques et al., 2014). However, the degree to which this is true across different types of anthropogenic habitats and to what extent this leads to a decrease or even loss in freshwater mussel populations remains to be assessed. Mussels are thereby highly suitable for collecting the necessary empirical ecotoxicological data (Naimo, 1995).

Anthropogenic habitats can become ecological traps not only by changing the environmental characteristics but also by changing biotic interactions. For example, increased predation by the invasive crayfish Procambarus clarkii on Unio mancus was recorded in a Spanish water mill canal compared to adjacent natural habitats ( $\mathrm{K}$. Nakamura, personal observation, May, 2019). This was probably caused by the lower heterogeneity in the anthropogenic compared to the natural ecosystems, thus reducing the capacity of prey (particularly juveniles) to escape predators (Meira et al., 2019; Sousa, Nogueira, Ferreira, et al., 2019). Competition between native and non-native species for food and space can also be a problem, as many anthropogenic habitats are heavily invaded by non-native bivalve species, including $C$. fluminea, $S$. woodiana, D. polymorpha and D. bugensis (see Table S1; Sousa et al., 2014). For example, in the neighbourhood of Międzyodrze (protected area in Poland), establishment of a channel for discharging the thermally polluted water of a power plant created an anthropogenic heat island that does not freeze in winter and is thus used for cage fish farming throughout the year (Figure 4). The channel is nowadays a suitable habitat for nonnative species, including some species from tropical and subtropical climate zones (e.g. the fish Lepomis gibbosus, shrimp Neocaridina davidi, crayfish Orconectes limosus and bivalves such as S. woodiana, Corbicula sp. and D. polymorpha; Jablonska et al., 2018; Labecka \& Czarnoleski, 2019; Labecka et al., 2005). The presence of these nonnative species may directly or indirectly impair the survival of the native mussel species A. anatina, A. cygnea (protected in Poland), Unio tumidus and Unio pictorum (Ożgo et al., 2020). Particularly worrisome in anthropogenic habitats is $S$. woodiana, given their widespread distribution and because this species may reproduce continuously throughout the year (Labecka \& Domagala, 2018), might even be many times more fecund compared to the native unionids (Labecka \& Czarnoleski, 2019) and the presence of its glochidia on fish hosts can limit the metamorphosis of the co-occurring larvae of native unionid species (Donrovich et al., 2017). Some non-native invasive bivalves have even been shown to ingest and kill glochidia of native mussels by filtration (Modesto et al., 2019), which would be expected to be exacerbated in restricted anthropogenic habitats with low volumes of water (e.g. irrigation canals, small artificial ponds). Recruitment of freshwater mussels can further be affected by altered biotic interactions (predation, competition; Cucherousset \& Olden, 2011) between non-native and native fishes, potentially causing complete displacement of fish hosts. Interestingly, anthropogenic habitats 
FIGURE 4 View of the thermally polluted channel in the neighbourhood of Międzyodrze showing fish cages (photo credit: Bartłomiej Szpakowski) [Colour figure can be viewed at wileyonlinelibrary. com]

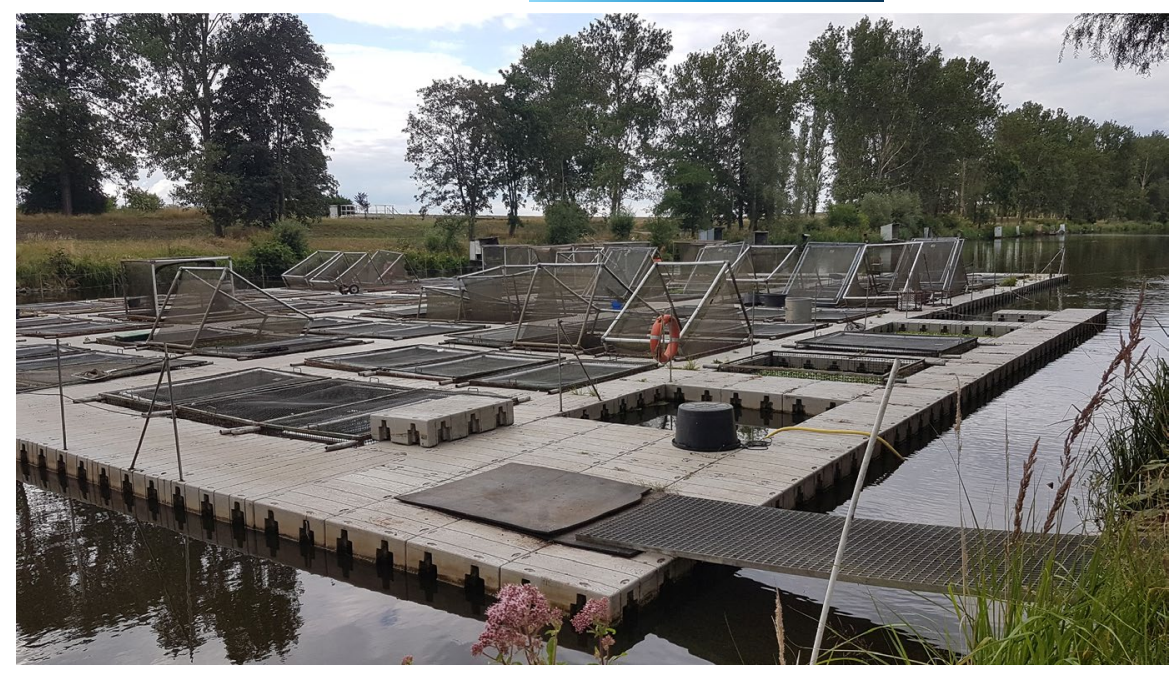

may also function as an ecological trap for freshwater mussels with particular reproductive behaviours. For example, the spurting behaviour of some $U$. crassus (Endangered) populations may be impaired by channelisation. In this species, gravid females migrate to the river margin for 3-6 h, where they spurt water jets laden with glochidia until their marsupia are emptied. This behaviour seems to attract the fish hosts, increasing the likelihood of glochidia encysting on suitable fish hosts (Vincentini, 2005). Therefore, disturbances in river margins may negatively affect this European musse (but see Stoeckl \& Geist, 2016 and Table S1 with examples of recruiting populations in anthropogenic habitats). We are not aware of similar studies addressing the possible effects of anthropogenic habitats impairing the reproductive behaviour of mussels, but given the myriad of different strategies described (Modesto et al., 2018), other species may face similar problems and this situation deserves further investigation. Finally, some of these structures may have effects even in adjacent areas. Surveys by Hamstead et al. (2019) in the East Fork Tombigbee River, which was affected by the construction of the Tennessee-Tombigbee Waterway (Alabama, USA), one of the largest $(377 \mathrm{~km})$ and most expensive environmental engineering projects of the 20th century, show that, although mussel abundance and richness remained relatively stable, the species composition changed significantly.

\section{I MANAGEMENT MEASURES FOR THE CONSERVATION OF FRESHWATER MUSSELS IN ANTHROPOGENIC HABITATS}

In a world almost totally dominated by humans and their infrastructures, there is no doubt that anthropogenic habitats will grow in number and spatial extent in the future. For example, 3700 hydropower dams larger than $1 \mathrm{MW}$ are currently proposed or under construction, and many more dams of smaller size are expected to be built to address the increasing global demands for energy, flood control and irrigation (Thieme et al., 2020; Zarfl et al., 2015). A similar situation is true for canals, as, for example, dozens of water transfer megaprojects (i.e. large-scale engineering interventions to divert water within and between river basins; Shumilova et al., 2018) are planned for the near future (Daga et al., 2020; Shumilova et al., 2018; Zhan et al., 2015; Zhuang, 2016). Therefore, the ecological, conservational and socio-economic importance of anthropogenic habitats should not be ignored and are expected to increase.

The social functions and services of anthropogenic habitats may change through time and influence management objectives. For instance, shifting from a focus on commercial shipping to recreational activities and heritage preservation or replacing old irrigation canals with modern irrigation technologies may result in the deactivation or even the destruction of some anthropogenic habitats (Hijdra et al., 2014; Lin et al., 2020; Walker et al., 2010). These situations should be carefully evaluated, since some of these anthropogenic habitats may be colonised by freshwater mussels and other species of conservation interest.

Environmental and biological differences between anthropogenic and natural habitats are in some cases minor and can frequently be overcome by ecological engineering, to make the environment more suitable for freshwater mussels and other native species, and/or assisted dispersal to allow suitable native organisms to reach these artificial ecosystems (Lundholm \& Richardson, 2010). Sometimes minor ecological engineering activities can create habitats suitable for biodiversity conservation (e.g. adding appropriate substrate and controlling hydroperiods) that mimic natural conditions. The implementation of measures that can increase habitat heterogeneity (addition of wood or large boulders, increased refuges) and the use of more environmentally friendly materials in channelised rivers (e.g. deposition of substrate with appropriate grain sizes, use of permeable materials other than concrete) can better suit freshwater mussels (and other species) and even improve ecosystem services such as flood control and recreation appeal (Geist, 2011). There is a lot to be learned on this topic from anthropogenic habitats located in marine ecosystems (see e.g. Strain et al., 2018). Similarly, careful management of water levels in these anthropogenic habitats using, for example, remote sensing techniques to assess spatial and temporal changes in hydroperiod (see Kissel et al., 2020; Box 3), especially during drought conditions, may be key to decrease mortality. In fact, many dams already have small-scale data monitoring programmes 


\section{BOX 3 Research needs and a way forward}

Our understanding of how anthropogenic habitats affect freshwater mussels is in its infancy, with more questions than answers (i.e. some examples showing their conservation importance and others showing their role as ecological traps). Therefore, careful ecological comparisons should be made taking into account appropriate spatial and temporal scales. Connectivity and time since construction may be key aspects to pay attention to, since we predict that increased connectivity and older structures will allow succession to a more stable community, with an increase in the diversity and abundance of freshwater mussel species. Another key aspect to take into account is the type of material used in the construction of these structures. For example, the conservation value of a fully concrete canal would be expected to be very different from a canal with natural sediments. For a benthic species, such as a freshwater mussel, this situation should be carefully evaluated and guide the future implementation of nature based solutions (see Palmer et al., 2015). Given the dominance of structures made of concrete in aquatic ecosystems and due to their negative effects on many ecological aspects (for a review, see Cooke et al., 2020), future studies should aim at developing more eco-friendly and sustainable materials. These new materials, including more permeable concrete and fibrous materials such as fuzzy ropes (Cooke et al., 2020), may not only benefit biota but also humans (e.g. through improved biogeochemical cycling), with lower environmental, social and economic costs (Palmer et al., 2015).

Future research should involve the development of monitoring programmes focused on the comparison of anthropogenic habitats with adjacent natural ecosystems. New and emerging tools such as remote sensing technologies and environmental DNA can be a great help not only to detect rare and invasive species but also to characterise adjacent terrestrial ecosystems (Prié et al., 2020; Togaki et al., 2020). Data generated by novel remote-sensing techniques, such as aerial imagery to estimate surface area and hydroperiod (see Kissel et al., 2020), may be key to better understand the hydrologic dynamics of anthropogenic habitats. In the same vein, since anthropogenic habitats are affected by global stressors, such as habitat loss, pollution, invasive species and climate change, their effects should be evaluated simultaneously.

The social value of anthropogenic habitats is also particularly important to evaluate in the future, using, for example, local ecological knowledge and iEcology as well as culturomic tools (see Jarić et al., 2020; Sousa et al., 2020) to determine how the general public perceives these habitats in terms of conservation of biodiversity. In addition, studies assessing functional responses, such as filtration rates, nutrient cycling and bioturbation in anthropogenic compared to natural ecosystems, are totally inexistent and these gaps limit our understanding of the functional responses of freshwater mussels to these infrastructures. Finally, and although completely speculative given the inexistence of studies, these aquatic anthropogenic structures could have evolutionary implications (see Johnson \& Munshi-South, 2017; Schilthuizen, 2019 for urban areas). Freshwater mussels could be adapting to these anthropogenic habitats, and this situation could be extremely interesting to investigate in the future.

in place to ensure that water levels do not reach critical levels and these programmes can be used to better manage river levels and decrease mussel die-offs.

Simple measures could be applied in specific freshwater habitats with high conservation importance, which need ongoing habitat maintenance. For example, in the Bouhlou irrigation canal system (Morocco), channel cleaning activities used to be undertaken without any attention to the needs of freshwater mussels (Sousa, Teixeira, et al., 2019). After the discovery of a P. marocanus population, an information campaign and educational outreach activities, aimed at informing the local farmers of the potentially damaging operations for the mussels, were conducted. Since this was introduced, mussel mortality caused by cleaning or management activities in this system has been reduced by implementing simple measures, such as sorting the sediments for the presence of mussels and returning these individuals to the irrigation canal or to adjacent natural riverine habitat. Removal of submerged vegetation from canals or artificial ponds can also result in mortality of freshwater mussels (Aldridge, 2000). Again, simple measures such as restricting dredging and weed removal operations to the centre of the river channel, where mussels are less abundant than on the margins, can significantly reduce mortality of freshwater mussels (Aldridge, 2000). Careless and unplanned maintenance works in some reservoirs may be also responsible for high mortalities in freshwater mussels. In the Corgo River, Portugal, during September 2017 maintenance activities on a small dam and the consequent drainage of its small reservoir resulted in the mortality of 2125 individuals, mainly A. anatina and a few U. delphinus (S. Varandas, personal observation, September, 2017; Figure 5). This situation could have been easily avoided if freshwater mussels had been relocated from the affected area (no more than $100 \mathrm{~m}$ of the river stretch) to upstream or downstream areas. In a contrasting example, in February 2018 maintenance works in a small dam located in the Tua River (Portugal) and consequent decrease in the water level of the reservoir was accompanied by the collection of thousands of unionids (A. anatina, $U$. delphinus and $P$. littoralis) from the exposed river banks and translocation to deeper areas (A. Teixeira, personal observation, February, 2018).

Anthropogenic freshwater ecosystems can be heavily invaded and function as a dispersal corridor for some non-native species. Many examples in this review show how these ecosystems have been colonised by S. woodiana, D. polymorpha and C. fluminea (Table S1). Early detection programmes using, for example, eDNA 
FIGURE 5 Bad management decisions resulted in massive mortalities of Anodonta anatina and Unio delphinus in a small reservoir in the Corgo River (Portugal) in September 2017. Most of the individuals were found dead in the right margin [Colour figure can be viewed at wileyonlinelibrary.com]

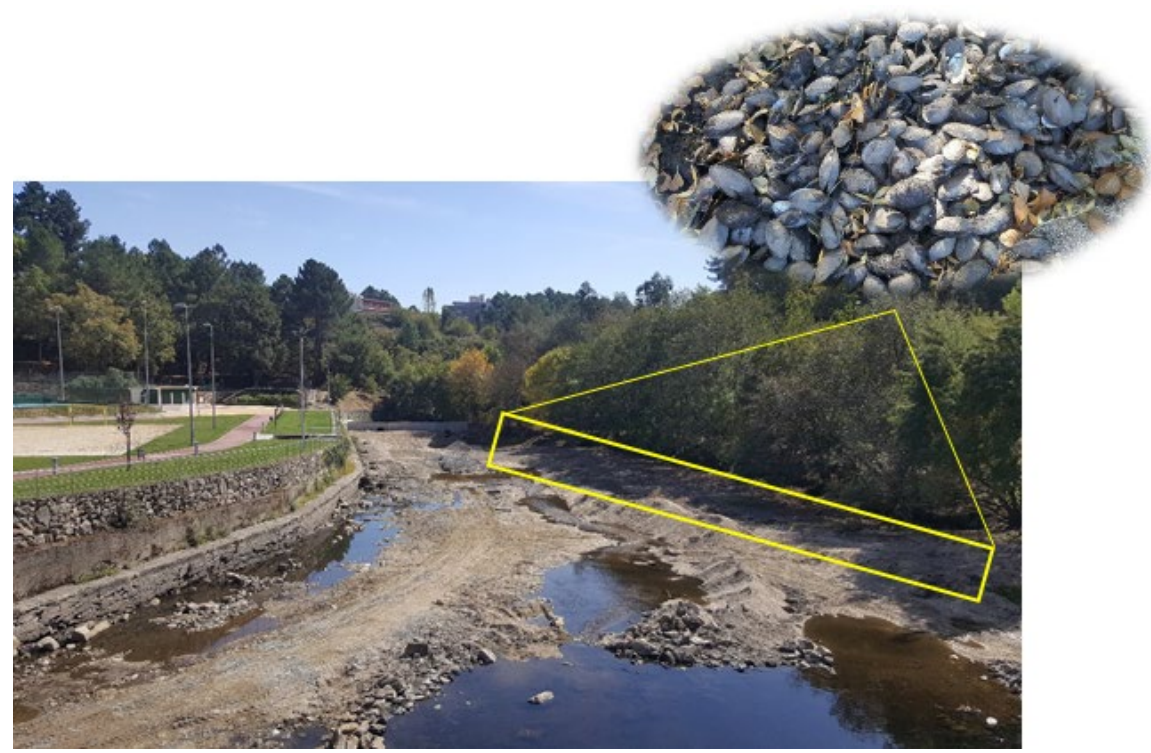

should be pursued, given the rate that these artificial habitats can be colonised by invasive species (Prié et al., 2020). For anthropogenic habitats already invaded, some control or even eradication programmes could be undertaken when necessary. In addition, the source of some invasive bivalve species could be easily controlled if more attention was given to monitoring and enforcement of fish stocks that are transported from foreign infested fish farms, as many different fish species from East Asia are infested by species of the genus Sinanodonta (Bespalaya et al., 2018; Huber \& Geist, 2019; Kondakov et al., 2020; Watters, 1997).

In recent years, dams have been removed in increasing numbers, as the reservoirs become filled with sediment, rendering them unsafe or inefficient, or have otherwise outlived their usefulness ( $O$ 'Connor et al., 2015). From 1950 to 2016, a total of 3869 dams have been removed globally, mostly in North America and Europe (Ding et al., 2019), to allow rivers to return to their natural states and improve connectivity. Whilst the impact of dam construction on freshwater biodiversity is well known (Grill et al., 2019), the effect of dam removals on freshwater mussels has rarely been quantified and the few available studies provide contradictory results. For example, Sethi et al. (2004) showed that the removal of a dam in Koshkonong Creek, Wisconsin (USA) led to high mortalities within the former impoundment area, due to stranding, and in downstream areas, due to sedimentation. Three years after removal these negative impacts persisted. By contrast, the removal of the small Dillsboro dam (3.5 m high) from the Tuckasegee River (North Carolina, USA) had major benefits for the Appalachian elktoe Alasmidonta raveneliana, a Critically Endangered species, where improved conditions were also reflected in the increase in populations of other macroinvertebrates such as mayflies, caddisflies and stoneflies, and lotic fish species. The contrasting effects are likely to be related to the different dam removal strategies adopted: in the first case, no attention was given to existing biodiversity and the removal was fast and in the second case, various mitigation measures for existing biodiversity were implemented, including the translocation of hundreds of mussels from areas immediately downstream of the dam, dredging of sand before dam removal and monitoring of abiotic parameters. Future studies should additionally look at quantifying the ecotoxicological effects of concrete dust loads resulting from dam removal on mussels and other filter-feeding organisms (Cooke et al., 2020). However, although financially costly, possible negative effects of dam removal on mussels can be minimised by translocating specimens.

Finally, and in certain cases, stable anthropogenic habitats may even be considered as an ultimate conservation tool. For example, long-lived freshwater mussels such as $P$. auricularius and $P$. marocanus can be translocated to suitable artificial habitats within the catchment providing refuges or arks to enable these species at high risk of extinction to continue reproduction and ultimately enable restocking of natural habitats. In other freshwater species, this approach has already been successful, such as in the case of the Azraq toothcarp Aphanius sirhani, a species of killifish that once lived in the Azraq wetland (Jordan). As this wetland dried due to water diversion to the city of Amman, all killifish disappeared. Fortunately, fish held by private aquariophilists were able to provide stock for their reintroduction to artificial fishponds constructed on the original Azraq wetland as arks (Freyhof \& Harrison, 2014).

Given the rapid rates of loss of freshwater biodiversity worldwide (Dudgeon et al., 2006), ubiquity of anthropogenic freshwater habitats and lack of knowledge about their potential role in freshwater biodiversity conservation, future studies are needed that carefully assess positive or negative effects on biodiversity, and the management implications of potentially competing ecological, economic and social objectives. In Figure 6 and Box 3, we propose a framework for future studies into the role of anthropogenic habitats in freshwater biodiversity conservation and the way forward in this topic. The rationale to study and find suitable management measures to maximise the conservation value of anthropogenic habitats should include: (1) identification of the type of anthropogenic habitat and full characterisation (area covered, materials used, environmental conditions, time since construction, hydrology, connectivity, species 


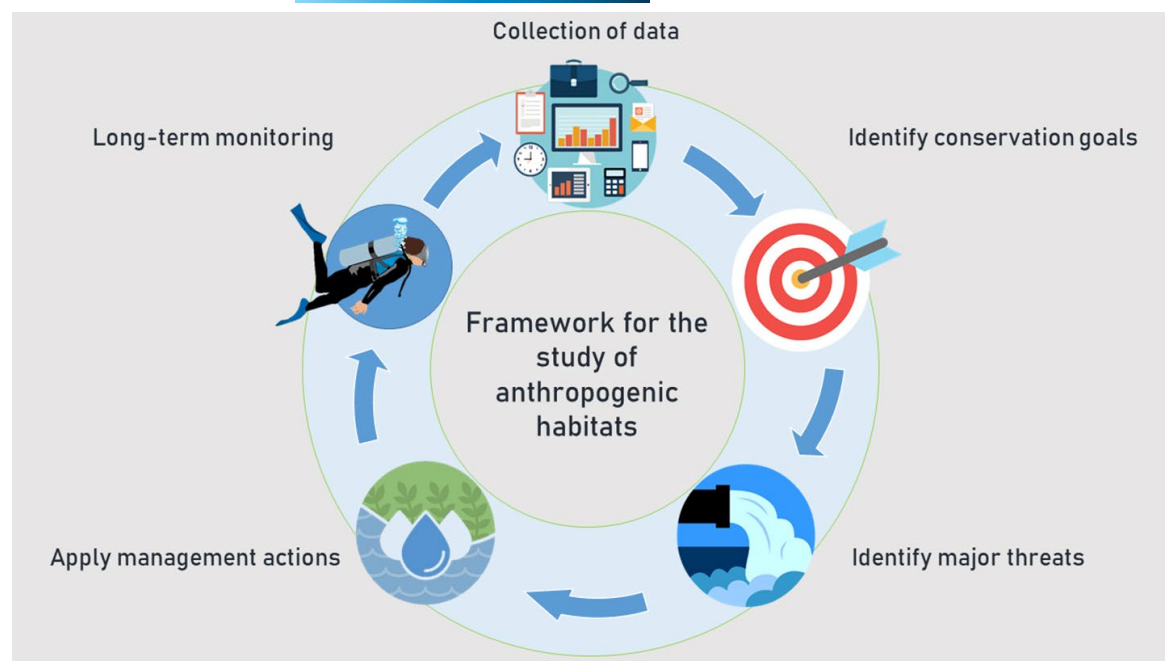

FIGURE 6 Summary of the major steps for the study of freshwater mussels in anthropogenic habitats, with eventual pay-offs in the form of better management and conservation of these (and other) species [Colour figure can be viewed at wileyonlinelibrary.com] present including special attention to the presence and abundance of fish hosts); (2) identification of their possible importance for the conservation of freshwater mussels and other organisms and full understanding of their ecological roles and interactions. It should be noted that from the 540 freshwater mussel species assessed on the IUCN Red List, only 41 have information regarding the possible importance of anthropogenic habitats. Therefore, future IUCN assessments should include, when possible, information about anthropogenic habitats and their importance to conserve freshwater mussels (and other species); (3) assessment of the main threats considering the effects at different spatial scales; (4) identification of those management measures which could enhance the quality (in terms of maintaining high biodiversity) of anthropogenic habitats, including consultation of stakeholders and citizens using outreach activities and creation of a manual of good practices for specific habitats and identification of potentially damaging operations; and (5) long-term monitoring including, where possible, the engagement of citizen scientists. Ideally, these long-term monitoring studies should compare the density, size structure and physiology of the animals that are living in anthropogenic with those in adjacent natural habitats.

\section{5 | CONCLUSION}

Human influence on freshwater habitats is now pervasive, and human activities and climate change have significantly altered the spatial and temporal distribution of surface water in the last decades (Pekel et al., 2016). This review has provided numerous examples of the conservation importance of anthropogenic habitats to one of the most endangered faunal groups on the planet. Some of these anthropogenic habitats physically replace natural ecosystems permanently, at least on relevant human timescales, which is in contrast to other threats that can be reversed (Latawiec et al., 2015). However, although anthropogenic habitats can sometimes mimic natural conditions and serve as refuges for freshwater mussels, there are cases where these systems may function as ecological traps. Anthropogenic habitats are therefore not a panacea for biodiversity protection.
The conservation importance of certain anthropogenic habitats should be carefully considered and evaluated, particularly as they are likely to become more widespread in the future. It will be crucial that the final decision on whether particular anthropogenic habitats are "worth" protecting takes into account the whole biodiversity rather than being made based on the effects on single species. Whilst we advocate that natural ecosystems should remain the primary focus for freshwater mussel conservation, anthropogenic habitats, although having less conservation value, also require attention, especially where natural ecosystems have been already extensively reduced or disturbed.

We anticipate an exciting proliferation of research on aquatic anthropogenic habitats over the next decade. This research will advance solutions to fundamental problems in ecology and conservation, given that these habitats provide large-scale, globally replicated experiments to understand how the replacement of natural habitats by anthropogenic habitats affects the species at distinct ecological levels, from individuals to ecosystems.

\section{ACKNOWLEDGEMENTS}

This publication is based upon work from COST Action CA18239, supported by COST (European Cooperation in Science and Technology). A.M.L. was financed by the Institute of Environmental Sciences Jagiellonian University (N18/DBS/000003) and K.N. by the Aragón Government. The authors acknowledge Jarosław Andrzejewski, Bartosz Czader, Anna Fica, Marcin Horbacz, Tomasz Jonderko, Steinar Kålås, Tomasz Kapela, Bjørn Mejdell Larsen, Maciej Pabijan, Katarzyna Pawlik, Ilona Popławska, Joanna Przybylska, Tomasz Przybył, Mateusz Rybak, Kjell Sandaas, Jarosław Słowikowski, Tomasz Szczasny, Michał Zawadzki and Paweł Zowada for providing detailed information on specific examples concerning freshwater mussels in anthropogenic habitats. We thank the editor and two anonymous referees for the valuable suggestions made, which increased the clarity of our manuscript.

\section{DATA AVAILABILITY STATEMENT}

The data that supports the findings of this study are available in the supplementary material of this article. 


\section{ORCID}

Ronaldo Sousa (D) https://orcid.org/0000-0002-5961-5515

Dariusz Halabowski (D) https://orcid.org/0000-0001-5841-559X

Anna M. Labecka (D) https://orcid.org/0000-0002-8810-7093

Juergen Geist (D) https://orcid.org/0000-0001-7698-3443

Manuel Lopes-Lima (D) https://orcid.org/0000-0002-2761-7962

Joana G. Nogueira (D) https://orcid.org/0000-0002-5576-3625

\section{REFERENCES}

Albrecht, C., Bodon, M., Cianfanelli, S., Giusti, F., \& Manganelli, G. (2011). Microcondylaea bonellii. The IUCN Red List of Threatened Species. https://doi.org/10.2305/IUCN.UK.2011-2.RLTS.T155595A48 05631.en

Aldridge, D. C. (2000). The impacts of dredging and weed cutting on a population of freshwater mussels (Bivalvia: Unionidae). Biological Conservation, 95, 247-257. https://doi.org/10.1016/S0006 $-3207(00) 00045-8$

Araujo, R., \& Ramos, M. A. (1998). Margaritifera auricularia (Unionoidea, Margaritiferidae), the giant freshwater pearl mussel rediscovered in Spain. Graellsia, 54, 129-130.

Araujo, R., \& Ramos, M. A. (2000). Status and conservation of the giant European freshwater pearl mussel (Margaritifera auricularia) (Spengler, 1793) (Bivalvia: Unionoidea). Biological Conservation, 96, 233-239. https://doi.org/10.1016/S0006-3207(00)00075-6

Aspe, C., \& Jacqué, M. (2015). Agricultural irrigation canals in southern France and new urban territorial uses. Agriculture and Agricultural Science Procedia, 4, 29-39. https://doi.org/10.1016/ j.aaspro.2015.03.005

Barbarossa, V., Schmitt, R. J., Huijbregts, M. A., Zarfl, C., King, H., \& Schipper, A. M. (2020). Impacts of current and future large dams on the geographic range connectivity of freshwater fish worldwide. Proceedings of the National Academy of Sciences of the United Sciences of America, 117, 3648-3655. https://doi.org/10.1073/ pnas.1912776117

Barnosky, A. D. (2008). Megafauna biomass tradeoff as a driver of Quaternary and future extinctions. Proceedings of the National Academy of Sciences of the United Sciences of America, 105, 1154311548. https://doi.org/10.1073/pnas.0801918105

Beatty, S. J., \& Morgan, D. L. (2017). Rapid proliferation of an endemic galaxiid following eradication of an alien piscivore (Perca fluviatilis) from a reservoir. Journal of Fish Biology, 90, 1090-1097. https://doi. org/10.1111/jfb.13214

Beggel, S., \& Geist, J. (2015). Acute effects of salinity exposure on glochidia viability and host infection of the freshwater mussel Anodonta anatina (Linnaeus, 1758). Science of the Total Environment, 502, 659-665. https://doi.org/10.1016/j.scitotenv. 2014.09.067

Beran, L. (2019). Distribution and recent status of freshwater mussels of family Unionidae (Bivalvia) in the Czech Republic. Knowledge and Management of Aquatic Ecosystems, 420, 45. https://doi.org/ 10.1051/kmae/2019038

Bespalaya, Y. V., Bolotov, I. N., Aksenova, O. V., Gofarov, M. Y., Kondakov, A. V., Vikhrev, I. V., \& Vinarski, M. V. (2018). DNA barcoding reveals invasion of two cryptic Sinanodonta mussel species (Bivalvia: Unionidae) into the largest Siberian river. Limnologica, 69, 94-102. https://doi.org/10.1016/j.limno.2017.11.009

Brainwood, M., Burgin, S., \& Byrne, M. (2008). The role of geomorphology in substratum patch selection by freshwater mussels in the Hawkesbury-Nepean River (New South Wales) Australia. Aquatic Conservation: Marine and Freshwater Ecosystems, 18, 1285-1301. https://doi.org/10.1002/aqc.949

Byrne, M. (1998). Reproduction of river and lake populations of Hyridella depressa (Unionacea: Hyriidae) in New South Wales: Implications for their conservation. Hydrobiologia, 389, 29-43. https://doi.org/ 10.1023/A:1003528431775

Chester, E. T., \& Robson, B. J. (2013). Anthropogenic refuges for freshwater biodiversity: Their ecological characteristics and management. Biological Conservation, 166, 64-75. https://doi.org/10.1016/j. biocon.2013.06.016

Cooke, S. J., Bergman, J. N., Nyboer, E. A., Reid, A. J., Gallagher, A. J., Hammerschlag, N., Van de Riet, K., \& Vermaire, J. C. (2020). Overcoming the concrete conquest of aquatic ecosystems. Biological Conservation, 247, 108589. https://doi.org/10.1016/j. biocon.2020.108589

Cucherousset, J., \& Olden, J. D. (2011). Ecological impacts of nonnative freshwater fishes. Fisheries, 36, 215-230. https://doi.org/ 10.1080/03632415.2011.574578

Daga, V. S., Azevedo-Santos, V. M., Pelicice, F. M., Fearnside, P. M., Perbiche-Neves, G., Paschoal, L. R. P., Daniel, C., Cavallari, D. C., Erickson, J., Ruocco, A. M. C., Oliveira, I., Padial, A. A., \& Vitule, J. R. S. (2020). Water diversion in Brazil threatens biodiversity. Ambio, 49, 165-172. https://doi.org/10.1007/s13280-019-01189-8

Ding, L., Chen, L., Ding, C., \& Tao, J. (2019). Global trends in dam removal and related research: A systematic review based on associated datasets and bibliometric analysis. Chinese Geographical Science, 29, 1-12. https://doi.org/10.1007/s11769-018-1009-8

Donrovich, S. W., Douda, K., Plechingerová, V., Rylková, K., Horký, P., Slavík, O., Liu, H.-Z., Reichard, M., Lopes-Lima, M., \& Sousa, R. (2017). Invasive Chinese pond mussel Sinanodonta woodiana threatens native mussel reproduction by inducing cross-resistance of host fish. Aquatic Conservation: Marine and Freshwater Ecosystems, 27, 1325-1333. https://doi.org/10.1002/aqc.2759

Dudgeon, D., Arthington, A. H., Gessner, M. O., Kawabata, Z.-I., Knowler, D. J., Lévêque, C., Naiman, R. J., Prieur-Richard, A.-H., Soto, D., Stiassny, M. L. J., \& Sullivan, C. A. (2006). Freshwater biodiversity: Importance, threats, status and conservation challenges. Biological Reviews, 81, 163-182. https://doi.org/10.1017/S1464793105006950

Ellis, E. C., \& Ramankutty, N. (2008). Putting people in the map: Anthropogenic biomes of the world. Frontiers in Ecology and the Environment, 6, 439-447. https://doi.org/10.1890/070062

Falcucci, A., Maiorano, L., \& Boitani, L. (2007). Changes in land-use/ land-cover patterns in Italy and their implications for biodiversity conservation. Landscape Ecology, 22, 617-631. https://doi. org/10.1007/s10980-006-9056-4

Ferreira-Rodríguez, N., Akiyama, B. Y., Aksenova, O., Araujo, R., Barnhart, C., Bespalaya, Y., Bogan, A., Bolotov, I. N., Budha, P. B., Clavijo, C., Clearwater, S. J., Darrigran, G., Do, V. T., Douda, K., Froufe, E., Graf, D., Gumpinger, C., Humphrey, C. L., Johnson, N. A., ... Vaughn, C. C. (2019). Research priorities for freshwater mussel conservation assessment. Biological Conservation, 231, 77-87. https://doi. org/10.1016/j.biocon.2019.01.002

Freyhof, J., \& Harrison, I. J. (2014). Aphanius sirhani. The IUCN Red List of Threatened Species 2014:e.T60411A16580970. https://doi. org/10.2305/IUCN.UK.20141.RLTS.T60411A16580970.en

Geist, J. (2011). Integrative freshwater ecology and biodiversity conservation. Ecological Indicators, 11, 1507-1516. https://doi. org/10.1016/j.ecolind.2011.04.002

Geyer, B., \& Monchambert, J. Y. (2015). Canals and water supply in the lower Euphrates valley. Water History, 7, 11-37. https://doi. org/10.1007/s12685-014-0108-4

Ghosh, S., Mondal, A., Gangopadhyay, S., \& Mandal, S. (2020). Cadmium bioaccumulation in Lamellidens marginalis and human health risk assessment: A case study in India. Human and Ecological Risk Assessment: An International Journal, 26, 713-725. https://doi. org/10.1080/10807039.2018.1530588

Gomes-dos-Santos, A., Froufe, E., Gonçalves, D. V., Sousa, R., Prié, V., Ghamizi, M., Benaissa, H., Varandas, S., Teixeira, A., \& Lopes-Lima, M. (2019). Freshwater conservation assessments in (semi-)arid regions: Testing river intermittence and buffer strategies using 
freshwater mussels (Bivalvia, Unionida) in Morocco. Biological Conservation, 236, 420-434. https://doi.org/10.1016/j.biocon. 2019.05.038

Grill, G., Lehner, B., Thieme, M., Geenen, B., Tickner, D., Antonelli, F., Babu, S., Borrelli, P., Cheng, L., Crochetiere, H., Ehalt Macedo, H., Filgueiras, R., Goichot, M., Higgins, J., Hogan, Z., Lip, B., McClain, M. E., Meng, J., Mulligan, M., ... Zarfl, C. (2019). Mapping the world's free-flowing rivers. Nature, 569, 215-221. https://doi.org/10.1038/ s41586-019-1111-9

Haag, W. R. (2012). North American freshwater mussels: Natural history, ecology, and conservation. Cambridge University Press.

Haag, W. R., \& Warren, M. L. (2007). Freshwater mussel assemblage structure in a regulated river in the Lower Mississippi River Alluvial Basin, USA. Aquatic Conservation: Marine and Freshwater Ecosystems, 17, 25-36. https://doi.org/10.1002/aqc.773

Hamstead, B. A., Hartfield, P. D., Jones, R. L., \& Gangloff, M. M. (2019). Changes to freshwater mussel assemblages after 25 years of impoundment and river habitat fragmentation. Aquatic Conservation: Marine and Freshwater Ecosystems, 29, 2162-2175. https://doi. org/10.1002/aqc.3220

Hijdra, A., Arts, J., \& Woltjer, J. (2014). Do we need to rethink our waterways? Values of ageing waterways in current and future society. Water Resources Management, 28, 2599-2613. https://doi. org/10.1007/s11269-014-0629-8

Hoess, R., \& Geist, J. (2020). Spatiotemporal variation of streambed quality and fine sediment deposition in five freshwater pearl mussel streams, in relation to extreme drought, strong rain and snow melt. Limnologica, 85, 125833. https://doi.org/10.1016/j. limno.2020.125833

Hoffmann, R. C. (1996). Economic development and aquatic ecosystems in medieval Europe. The American Historical Review, 101, 631-669. https://doi.org/10.1086/ahr/101.3.631

Hronek, J. (2010). The occurrence and population characteristics of freshwater mussels (family Unionidae) on selected anthropogenically modified localities in the Czech Republic. Master Thesis (in Czech). Czech University of Life Sciences Prague.

Huber, V., \& Geist, J. (2019). Reproduction success of the invasive Sinanodonta woodiana (Lea 1834) in relation to native mussel species. Biological Invasions, 21, 3451-3465. https://doi.org/10.1007/ s10530-019-02060-3

IUCN. (2020). Red List version 2020-1.

Jabłońska, A., Mamos, T., Gruszka, P., Szlauer-Łukaszewska, A., \& Grabowski, M. (2018). First record and DNA barcodes of the aquarium shrimp, Neocaridina davidi, in Central Europe from thermally polluted River Oder canal, Poland. Knowledge and Management of Aquatic Ecosystems, 419, 14. https://doi.org/10.1051/kmae/2018004

Jarić, I., Roll, U., Arlinghaus, R., Belmaker, J., Chen, Y., China, V., Douda, K., Essl, F., Jähnig, S. C., Jeschke, J. M., Kalinkat, G., Kalous, L., Ladle, R., Lennox, R. J., Rosa, R., Sbragaglia, V., Sherren, K., Šmejkal, M., Soriano-Redondo, A., ... Correia, R. A. (2020). Expanding conservation culturomics and iEcology from terrestrial to aquatic realms. PLoS Biology, 18, e3000935. https://doi.org/10.1371/journal. pbio.3000935

Johnson, M. T., \& Munshi-South, J. (2017). Evolution of life in urban environments. Science, 358, eaam8327. https://doi.org/10.1126/scien ce.aam8327

Jones, H. A. (2007). The influence of hydrology on freshwater mussel (Bivalvia: Hyriidae) distributions in a semi-arid river system, the Barwon-Darling River and Intersecting Streams. In C. R. Dickman, S. Burgin, \& D. Lunney (Eds.), Animals of arid Australia: Out on their own? (pp. 132-142). Royal Zoological Society of NSW.

Jones, H. A. (2011). Crustaceans and molluscs. In K. Rogers \& T. J. Ralph (Eds.), Floodplain wetland biota in the Murray-Darling Basin: Water and habitat requirements (pp. 275-310). CSIRO Publishing.

Katayama, N., Baba, Y. G., Kusumoto, Y., \& Tanaka, K. (2015). A review of post-war changes in rice farming and biodiversity in Japan.
Agricultural Systems, 132, 73-84. https://doi.org/10.1016/j.agsy. 2014.09.001

Kingsford, R. T. (2000). Ecological impacts of dams, water diversions and river management on floodplain wetlands in Australia. Austral Ecology, 25, 109-127. https://doi.org/10.1046/j.1442-9993.2000. 01036.x

Kissel, A. M., Halabisky, M., Scherer, R. D., Ryan, M. E., \& Hansen, E. C. (2020). Expanding wetland hydroperiod data via satellite imagery for ecological applications. Frontiers in Ecology and the Environment, 18, 432-438. https://doi.org/10.1002/fee.2233

Klunzinger, M. W., Beatty, S. J., Morgan, D. L., Pinder, A. M., \& Lymbery, A. J. (2015). Range decline and conservation status of Westralunio carteri Iredale, 1934 (Bivalvia: Hyriidae) from south-western Australia. Australian Journal of Zoology, 63, 127-135. https://doi. org/10.1071/ZO15002

Klunzinger, M. W., Beatty, S. J., Morgan, D. L., Thomson, G. J., \& Lymbery, A. J. (2012). Glochidia ecology in wild fish populations and laboratory determination of competent host fishes for an endemic freshwater mussel of south-western Australia. Australian Journal of Zoology, 60, 26-36. https://doi.org/10.1071/ZO12022

Kondakov, A. V., Bespalaya, Y. V., Vikhrev, I. V., Konopleva, E. S., Gofarov, M. Y., Tomilova, A. A., Vinarski, M. V., \& Bolotov, I. N. (2020). The Asian pond mussels rapidly colonize Russia: Successful invasions of two cryptic species to the Volga and Ob rivers. Biolnvasions Records, 9, 504-518. https://doi.org/10.3391/bir.2020.9.3.07

Labecka, A. M., \& Czarnoleski, M. (2019). Patterns of growth, brooding and offspring size in the invasive mussel Sinanodonta woodiana (Lea, 1834) (Bivalvia: Unionidae) from an anthropogenic heat island. Hydrobiologia. https://doi.org/10.1007/s10750-019-04141-9

Labecka, A. M., \& Domagala, J. (2018). Continuous reproduction of Sinanodonta woodiana (Lea, 1824) females - An invasive mussel species in a female-biased population. Hydrobiologia, 810, 57-76. https://doi.org/10.1007/s10750-016-2835-2

Łabęcka, A. M., Domagała, J., \& Pilecka-Rapacz, M. (2005). First record of Corbicula fluminalis (O.F. Müller, 1774) (Bivalvia: Corbiculidae) in Poland. Folia Malacologica, 13, 25-27. https://doi.org/10.12657/ folmal.013.003

Latawiec, A. E., Strassburg, B. B., Brancalion, P. H., Rodrigues, R. R., \& Gardner, T. (2015). Creating space for large-scale restoration in tropical agricultural landscapes. Frontiers in Ecology and the Environment, 13, 211-218. https://doi.org/10.1890/140052

Lehner, B., Liermann, C. R., Revenga, C., Vörösmarty, C., Fekete, B., Crouzet, P., Döll, P., Endejan, M., Frenken, K., Magome, J., Nilsson, C., Robertson, J. C., Rödel, R., Sindorf, N., \& Wisser, D. (2011). High-resolution mapping of the world's reservoirs and dams for sustainable river-flow management. Frontiers in Ecology and the Environment, 9, 494-502. https://doi.org/10.1890/100125

Lin, H. Y., Cooke, S. J., Wolter, C., Young, N., \& Bennett, J. R. (2020). On the conservation value of historic canals for aquatic ecosystems. Biological Conservation, 251, 108764. https://doi.org/10.1016/j. biocon.2020.108764

Lopes-Lima, M., Burlakova, L. E., Karatayev, A. Y., Mehler, K., Seddon, M., \& Sousa, R. (2018). Conservation of freshwater bivalves at the global scale: Diversity, threats and research needs. Hydrobiologia, 810, 1-14. https://doi.org/10.1007/s10750-017-3486-7

Lopes-Lima, M., Sousa, R., Geist, J., Aldridge, D. C., Araujo, R., Bergengren, J., Bespalaya, Y., Bódis, E., Burlakova, L., Van Damme, D., Douda, K., Froufe, E., Georgiev, D., Gumpinger, C., Karatayev, A., Kebapçi, Ü., Killeen, I., Lajtner, J., Larsen, B. M., ... Zogaris, S. (2017). Conservation status of freshwater mussels in Europe: State of the art and future challenges. Biological Reviews, 92, 572-607. https:// doi.org/10.1111/brv.12244

Lopes-Lima, M., Teixeira, A., Froufe, E., Lopes, A., Varandas, S., \& Sousa, R. (2014). Biology and conservation of freshwater bivalves: Past, present and future perspectives. Hydrobiologia, 735, 1-13. https:// doi.org/10.1007/s10750-014-1902-9 
Lundholm, J. T., \& Richardson, P. J. (2010). Habitat analogues for reconciliation ecology in urban and industrial environments. Journal of Applied Ecology, 47, 966-975. https://doi.org/10.1111/j.1365-2664. 2010.01857.x

Lymbery, A. J., Ma, L., Lymbery, S. J., Klunzinger, M. W., Beatty, S. J. \& Morgan, D. L. (2020). Burrowing behavior protects a threatened freshwater mussel in drying rivers. Hydrobiologia. https://doi. org/10.1007/s10750-020-04268-0

McAllister, E., Craig, J. F., Davidson, N., Delany, S., \& Ii, M. S. (2001). Biodiversity Impacts of Large Dams. Background Paper, 1.

McMichael, D. F., \& Hiscock, I. D. (1958). A monograph of the freshwater mussels (Mollusca: Pelecypoda) of the Australian Region. Australian Journal of Marine and Freshwater Research, 9, 372-507. https://doi. org/10.1071/MF9580372

Meira, A., Lopes-Lima, M., Varandas, S., Teixeira, A., Arenas, F., \& Sousa, R. (2019). Invasive crayfishes as a threat to freshwater bivalves: Interspecific differences and conservation implications. Science of the Total Environment, 649, 938-948. https://doi.org/10.1016/j. scitotenv.2018.08.341

Miura, K., Izumi, H., Saito, Y., Asato, K., Negishi, J. N., Ito, K., \& Oomori, A. (2018). Assessment of a unionid freshwater mussel (Pronodularia japanensis) population in an agricultural channel during the 4 years following reintroduction. Landscape and Ecological Engineering, 14, 157-164. https://doi.org/10.1007/s11355-017-0330-1

Modesto, V., Castro, P., Lopes-Lima, M., Antunes, C., Ilarri, M., \& Sousa, R. (2019). Potential impacts of the invasive species Corbicula fluminea on the survival of glochidia. Science of the Total Environment, 673, 157-164. https://doi.org/10.1016/j.scitotenv.2019.04.043

Modesto, V., Ilarri, M., Souza, A. T., Lopes-Lima, M., Douda, K., Clavero, M., \& Sousa, R. (2018). Fish and mussels: Importance of fish for freshwater mussel conservation. Fish and Fisheries, 19, 244-259. https://doi.org/10.1111/faf.12252

Naimo, T. J. (1995). A review of the effects of the heavy metals on freshwater mussels. Ecotoxicology, 4, 341-362. https://doi.org/10.1007/ BF00118870

Nakajima, T., Hudson, M. J., Uchiyama, J., Makibayashi, K., \& Zhang, J. (2019). Common carp aquaculture in Neolithic China dates back 8,000 years. Nature Ecology \& Evolution, 3, 1415-1418. https://doi. org/10.1038/s41559-019-0974-3

Nakamura, K., Cañete, J., Vijuesca, D., Guillén, N., Sosa, C., MesquitaJoanes, F., Sousa, R., Ginés, E., \& Sorribas, V. (2020). Sensitivity of Pseudunio auricularius to metals and ammonia: First evaluation. Hydrobiologia. https://doi.org/10.1007/s10750-020-04277-z

Nakamura, K., Cucala, L., Mestre, A., Mesquita-Joanes, F., Elbaile, E., Salinas, C., \& Muñoz-Yanguas, M. A. (2018). Modelling growth in the critically endangered freshwater mussel Margaritifera auricularia (Spengler, 1793) in the Ebro basin. Hydrobiologia, 810, 375391. https://doi.org/10.1007/s10750-017-3103-9

Nakamura, K., Guerrero, J., Alcántara, M., Muñoz, M. A., \& Elbaile, E. (2018). Tiempos de incertidumbre para la náyade Margaritifera auricularia. Quercus, 383, 16-24.

Natuhara, Y. (2013). Ecosystem services by paddy fields as substitutes of natural wetlands in Japan. Ecological Engineering, 56, 97-106. https://doi.org/10.1016/j.ecoleng.2012.04.026

O'Connor, J. E., Duda, J. J., \& Grant, G. E. (2015). 1000 dams down and counting. Science, 348, 496-497. https://doi.org/10.1126/science. aaa9204

Ortloff, C. R. (2009). Water engineering in the ancient world: Archaeological and climate perspectives on societies of ancient South America, the Middle East, and South-East Asia. Oxford University Press.

Ożgo, M., Urbańska, M., Hoos, P., Imhof, H. K., Kirschenstein, M., Mayr, J., Michl, F., Tobiasz, R., von Wesendonk, M., Zimmermann, S., \& Geist, J. (2020). Invasive zebra mussel (Dreissena polymorpha) threatens an exceptionally large population of the depressed river mussel (Pseudanodonta complanata) in a postglacial lake. Ecology and Evolution, 10, 4918-4927. https://doi.org/10.1002/ece3.6243
Palanques, A., Grimalt, J., Belzunces, M., Estrada, F., Puig, P., \& Guillén, G. (2014). Massive accumulation of highly polluted sedimentary deposits by river damming. Science of the Total Environment, 497-498, 369-381. https://doi.org/10.1016/j.scitotenv.2014.07.091

Palmer, M. A., Liu, J., Matthews, J. H., Mumba, M., \& D'Odorico, P. (2015). Manage water in a green way. Science, 349, 584-585. https://doi. org/10.1126/science.aac7778

Paschoal, L. R., Andrade, D. P., Pimpão, D. M., Torres, S., \& Darrigran, G. (2020). Massive mortality of the giant freshwater mussel Anodontites trapesialis (Lamarck, 1819) (Bivalvia: Mycetopodidae) during a severe drought in a Neotropical reservoir. Anais da Academia Brasileira de Ciências, 92, e20180811. https://doi.org/10.1590/0001-37652 02020180811

Pekel, J. F., Cottam, A., Gorelick, N., \& Belward, A. S. (2016). High-resolution mapping of global surface water and its long-term changes. Nature, 540, 418-422. https://doi.org/10.1038/nature20584

Prié, V., Soler, J., Araújo, R., Cucherat, X., Philippe, L., Patry, N., Adam, B., Legrand, N., Jugé, P., Richard, N., \& Wantzen, K. M. (2018). Challenging exploration of troubled waters: A decade of surveys of the giant freshwater pearl mussel Margaritifera auricularia in Europe. Hydrobiologia, 810, 157-175. https://doi.org/10.1007/s1075 0-017-3456-0

Prié, V., Valentini, A., Lopes-Lima, M., Froufe, E., Rocle, M., Poulet, N., Taberlet, P., \& Dejean, T. (2020). Environmental DNA metabarcoding for freshwater bivalves biodiversity assessment: Methods and results for the Western Palearctic (European sub-region). Hydrobiologia. https://doi.org/10.1007/s10750-020-04260-8

Pulliam, H. R. (1988). Sources, sinks, and population regulation. American Naturalist, 132, 652-661. https://doi.org/10.1086/284880

Revenga, C., Brunner, J., Henninger, N., Kassem, K., \& Payne, R. (2000). Pilot analysis of global ecosystems: Freshwater systems. World Resources Institute.

Rosenzweig, M. L. (2003). Win-Win ecology: How the earth's species can survive in the midst of human enterprise. Oxford University Press.

Roy, K., Vrba, J., Kaushik, S. J., \& Mraz, J. (2020). Nutrient footprint and ecosystem services of carp production in European fishponds in contrast to EU crop and livestock sectors. Journal of Cleaner Production, 270, 122268. https://doi.org/10.1016/j.jclepro.2020.122268

Schilthuizen, M. (2019). Darwin comes to town: How the urban jungle drives evolution. Picador.

Schlaepfer, M. A., Runge, M. C., \& Sherman, P. W. (2002). Ecological and evolutionary traps. Trends in Ecology and Evolution, 17, 474-480. https://doi.org/10.1016/S0169-5347(02)02580-6

Schmutz, S., \& Sendzimir, J. (2018). Riverine ecosystem management: Science for governing towards a sustainable future. Springer Nature.

Sethi, S. A., Selle, A. R., Doyle, M. W., Stanley, E. H., \& Kitchel, H. E. (2004). Response of unionid mussels to dam removal in Koshkonong Creek, Wisconsin (USA). Hydrobiologia, 525, 157-165. https://doi. org/10.1023/B:HYDR.0000038862.63229.56

Shumilova, O., Tockner, K., Thieme, M., Koska, A., \& Zarfl, C. (2018). Global water transfer megaprojects: A potential solution for the water-food-energy nexus? Frontiers in Environmental Science, 6, 150. https://doi.org/10.3389/fenvs.2018.00150

Smith, B. D. (2007). The ultimate ecosystem engineers. Science, 315, 1797-1798. https://doi.org/10.1126/science.1137740

Smith, N. A. F. (1971). A history of dams. Citadel Press.

Sousa, R., Ferreira, A., Carvalho, F., Lopes-Lima, M., Varandas, S., \& Teixeira, A. (2018). Die-offs of the endangered pearl mussel Margaritifera margaritifera during an extreme drought. Aquatic Conservation: Marine and Freshwater Ecosystems, 28, 1244-1248. https://doi.org/10.1002/aqc.2945

Sousa, R., Ferreira, A., Carvalho, F., Lopes-Lima, M., Varandas, S., Teixeira, A., \& Gallardo, B. (2020). Small hydropower plants as a threat to the endangered pearl mussel Margaritifera margaritifera. Science of the Total Environment, 719, 137361. https://doi.org/10.1016/j.scito tenv.2020.137361 
Sousa, R., Nogueira, J., Ferreira, A., Carvalho, F., Lopes-Lima, M. Varandas, S., \& Teixeira, A. (2019). A tale of shells and claws: the signal crayfish as a threat to the pearl mussel Margaritifera margaritifera in Europe. Science of the Total Environment, 665, 329-337. https://doi.org/10.1016/j.scitotenv.2019.02.094

Sousa, R., Nogueira, J. G., Lopes-Lima, M., Varandas, S., \& Teixeira, A. (2019). Water mill canals as habitat for Margaritifera margaritifera: Stable refuge or an ecological trap? Ecological Indicators, 106, 105469. https://doi.org/10.1016/j.ecolind.2019.105469

Sousa, R., Nogueira, J. G., Miranda, F., \& Teixeira, A. (2020). Time travelling through local ecological knowledge regarding an endangered species. Science of the Total Environment, 739, 140047. https://doi. org/10.1016/j.scitotenv.2020.140047

Sousa, R., Novais, A., Costa, R., \& Strayer, D. (2014). Invasive bivalves in fresh waters: Impacts from individuals to ecosystems and possible control strategies. Hydrobiologia, 735, 233-251. https://doi. org/10.1007/s10750-012-1409-1

Sousa, R., Teixeira, A., Benaissa, H., Varandas, S., Ghamizi, M., \& Lopes-Lima, M. (2019). Refuge in the sāqya: Irrigation canals as habitat for one of the world's 100 most threatened species. Biological Conservation, 238, 108209. https://doi.org/10.1016/j.biocon.2019.108209

Sousa, R., Teixeira, A., Santos, A., Benaissa, H., Varandas, S., Ghamizi, M., Prié, V., Froufe, E., \& Lopes-Lima, M. (2018). Oued Bouhlou: A new hope for the Moroccan pearl mussel. Aquatic Conservation: Marine and Freshwater Ecosystems, 28, 247-251. https://doi.org/10.1002/ aqc. 2825

Sousa, R., Varandas, S., Teixeira, A., Ghamizi, M., Froufe, E., \& LopesLima, M. (2016). Pearl mussels (Margaritifera marocana) in Morocco: Conservation status of the rarest bivalve in African fresh waters. Science of the Total Environment, 547, 405-412. https://doi. org/10.1016/j.scitotenv.2016.01.003

Stoeckl, K., \& Geist, J. (2016). Hydrological and substrate requirements of the thick-shelled river mussel Unio crassus (Philipsson 1788) Aquatic Conservation: Marine and Freshwater Ecosystems, 26, 456469. https://doi.org/10.1002/aqc.2598

Strain, E. M. A., Olabarria, C., Mayer-Pinto, M., Cumbo, V., Morris, R. L., Bugnot, A. B., Dafforn, K. A., Heery, E., Firth, L. B., Brooks, P. R., \& Bishop, M. J. (2018). Eco-engineering urban infrastructure for marine and coastal biodiversity: Which interventions have the greatest ecological benefit? Journal of Applied Ecology, 55, 426-441. https://doi.org/10.1111/1365-2664.12961

Strayer, D. L. (2008). Freshwater mussel ecology: A multifactor approach to distribution and abundance. University of California Press.

Strayer, D. L., Downing, J. A., Haag, W. R., King, T. L., Layzer, J. B., Newton, T. J., \& Nichols, J. S. (2004). Changing perspectives on pearly mussels, North America's most imperiled animals. BioScience, 54, 429439. https://doi.org/10.1641/0006-3568(2004)054[0429:CPOPM $\mathrm{N}] 2.0 . \mathrm{CO} ; 2$

Thieme, M. L., Khrystenko, D., Qin, S., Golden Kroner, R. E., Lehner, B., Pack, S., Tockner, K., Zarfl, C., Shahbol, N., \& Mascia, M. B. (2020). Dams and protected areas: Quantifying the spatial and temporal extent of global dam construction within protected areas. Conservation Letters, 13, e12719. https://doi.org/10.1111/conl.12719

Togaki, D., Doi, H., \& Katano, I. (2020). Detection of freshwater mussels (Sinanodonta spp.) in artificial ponds through environmental DNA: A comparison with traditional hand collection methods. Limnology, 21, 59-65. https://doi.org/10.1007/s10201-019-00584-0

Vincentini, H. (2005). Unusual spurting behaviour of the freshwater mussel Unio crassus. Journal of Molluscan Studies, 71, 409-410. https:// doi.org/10.1093/mollus/eyi045
Walker, K. F. (1981). Ecology of freshwater mussels in the River Murray. Australian Government Publishing Service.

Walker, K. F. (2017). Reproductive phenology of river and lake populations of freshwater mussels (Unionida: Hyriidae) in the River Murray. Molluscan Research, 37, 31-44. https://doi.org/10.1080/13235 818.2016.1206166

Walker, K. F., Thoms, M. C., \& Sheldon, F. (1992). Effects of weirs on the littoral environment of the River Murray, South Australia. In P. J. Boon, P. A. Calow, \& G. E. Petts (Eds.), River conservation and management (pp. 270-293). Wiley.

Walker, R. P., O'Toole, A. C., Whynot, Z., Hanson, K. C., \& Cooke, S. J. (2010). Evaluation of the aquatic habitat and fish assemblage in an urban reach of the historic Rideau Canal, Ottawa, Canada: Implications for management in an engineered system. Urban Ecosystems, 13, 563-582. https://doi.org/10.1007/s1125 2-010-0135-6

Watters, G. T. (1997). A synthesis and review of the expanding range of the Asian freshwater mussel Anodonta woodiana (Lea, 1834) (Bivalvia, Unionidae). The Veliger, 40, 152-156.

Zarfl, C., Lumsdon, A. E., Berlekamp, J., Tydecks, L., \& Tockner, K. (2015). A global boom in hydropower dam construction. Aquatic Sciences, 77, 161-170. https://doi.org/10.1007/s00027-014-0377-0

Zhan, A., Zhang, L., Xia, Z., Ni, P., Xiong, W., Chen, Y., Haffner, G. D., \& Maclsaac, H. J. (2015). Water diversions facilitate spread of nonnative species. Biological Invasions, 17, 3073-3080. https://doi. org/10.1007/s10530-015-0940-1

Zhuang, W. (2016). Eco-environmental impact of inter-basin water transfer projects: A review. Environmental Science and Pollution Research, 23, 12867-12879. https://doi.org/10.1007/s11356-016-6854-3

Zieritz, A., Bogan, A. E., Froufe, E., Klishko, O., Kondo, T., Kovitvadhi, U., Kovitvadhi, S., Lee, J. H., Lopes-Lima, M., Pfeiffer, J. M., Sousa, R., Do, V. T., Vikhrev, I., \& Zanatta, D. T. (2018). Diversity, biogeography and conservation of freshwater mussels (Bivalvia: Unionida) in East and Southeast Asia. Hydrobiologia, 810, 29-44. https://doi. org/10.1007/s10750-017-3104-8

Zieritz, A., Bogan, A. E., Rahim, K. A., Sousa, R., Jainih, L., Harun, S., Razak, N. F. A., Gallardo, B., McGowan, S., Hassan, R., \& LopesLima, M. (2018). Changes and drivers of freshwater mussel diversity and distribution in northern Borneo. Biological Conservation, 219, 126-137. https://doi.org/10.1016/j.biocon.2018.01.012

Zieritz, A., Lopes-Lima, M., Bogan, A., Sousa, R., Walton, S., Rahim, K., Wilson, J.-J., Ng, P.-Y., Froufe, E., \& McGowan, S. (2016). Factors driving changes in freshwater mussel (Bivalvia, Unionida) diversity and distribution in Peninsular Malaysia. Science of the Total Environment, 571, 1069-1078. https://doi.org/10.1016/j.scitotenv. 2016.07.098

\section{SUPPORTING INFORMATION}

Additional supporting information may be found online in the Supporting Information section.

How to cite this article: Sousa R, Halabowski D, Labecka AM, et al. The role of anthropogenic habitats in freshwater mussel conservation. Glob Change Biol. 2021;27:2298-2314. https:// doi.org/10.1111/gcb.15549 